\title{
To split or not to split Anthracotherium? A phylogeny of Anthracotheriinae (Cetartiodactyla: Hippopotamoidea) and its palaeobiogeographical implications
}

\author{
LAURELINE SCHERLER ${ }^{1 *}$, FABRICE LIHOREAU ${ }^{1 *}$ and DAMIEN BECKER ${ }^{2,3}$ \\ ${ }^{1} I S E M$, Université de Montpellier, CNRS, IRD, EPHE, Montpellier, France \\ 2JURASSICA Museum, Route de Fontenais 21, CH-2900 Porrentruy, Switzerland \\ ${ }^{3}$ Département de Géosciences, Université de Fribourg, Chemin du Musée 6, CH-1700 Fribourg, \\ Switzerland
}

\begin{abstract}
Since its first erection almost 200 years ago, palaeontologists have assigned to the genus Anthracotherium many species, some with dubious descriptions. Although it is a key taxon for specifying the invasion of Europe by terrestrial mammals during the well-studied Grande Coupure Event at the beginning of the Oligocene, the genus has never been reviewed before. A recent interest in the relationships of anthracotheres and hippopotamids highlighted its importance for the understanding of diversity of anthracotheres. Herein, we conduct a systematic review of most European anthracotheriine species, including some Asian and American species in order to establish a more exhaustive anthracotheriine phylogeny. A cladistic analysis focusing on anthracotheriines supports us in redefining and clarifying the systematic status of most genera and species of this subfamily. Furthermore, our study results in the division of Anthracotherium into two different genera, the definition of a new taxon, Paenanthracotherium gen. nov., and the creation of a new species from previously described material, Paenanthracotherium bergeri sp. nov. Additionally, our phylogeny suggests a new palaeogeographical scenario implying several dispersal events from Asia to Europe before and during the Grande Coupure Event. This study marks the first step to a much-needed global review of anthracotheriines, including the American and Asian specimens.
\end{abstract}

ADDITIONAL KEYWORDS: cladistic analysis - Eocene - Eurasia - Oligocene - new genus - new species taxonomic revision.

\section{INTRODUCTION}

Anthracotheriidae (Boisserie et al., 2005) is a paraphyletic family of cetartiodactyls, known since the description of the genus Anthracotherium by Cuvier (1822). Anthracotheres occurred in Asia, Europe, Africa and North and Central America from the Bartonian (late Middle Eocene) to the Early Pleistocene (for review, see Lihoreau \& Ducrocq, 2007; Rincon et al., 2013). This group of large mammals gained attention during the debate on hippopotamid origin and its relationship with cetaceans (for review, see Boisserie et al., 2011). These phylogenetic problems seem to

*Correspondingauthors.E-mail:laureline.scherler@net2000.ch, fabrice.lihoreau@umontpellier.fr

[http://zoobank.org/

urn:1sid:zoobank.org:pub:CA9851BF-

9539-47F3-8B6C-9E03DB044C77] be related to the high diversity of anthracotheres (Boisserie et al., 2005, 2010; Orliac et al., 2010; Lihoreau et al., 2015). Therefore, attempts to resolve the phylogeny of anthracotheres have been proposed, but they mainly focused on the bothriodontines, the bestsupported subfamily of anthracotheres closely related to Hippopotamidae. As Hippopotamidae is supposed to be part of Anthracotheriidae, a complete revision of the latter is needed to resolve its systematics by first focusing on its relationship with Hippopotamidae.

We present a phylogenetic analysis of the subfamily Anthracotheriinae, which includes the genera Heptacodon, Anthracotherium and Prominatherium (Lihoreau \& Ducrocq, 2007). Although well constrained in previous phylogenetic analyses (e.g. Kron \& Manning, 1998; Lihoreau et al., 2004; Tsubamoto et al., 2011), none of these studies analysed a comprehensive list of species. A common problem was the taxonomic ambiguity of 
some representatives, for example Anthracothema, Heothema, Anthracohyus, Myaingtherium and some Anthracokeryx species, that were synonymized with Anthracotherium or assigned to one of those genera (see Ducrocq, 1999; Tsubamoto et al., 2002, 2011; Soe, 2008). Moreover, Anthracotherium includes numerous species from both Europe and Asia, but the specimens display very different cheek teeth. Not only were subgeneric subdivisions proposed without a detailed revision of the species (Kowalesky, 1873; Stehlin, 1910; Sieber, 1935), but most of the material was never reviewed, with the exception of the Swiss material (Scherler, 2011) and the up-to-date description of Anthracotherium monsvialense De Zigno, 1888 (Ghezzo \& Giusberti, 2016). However, even if the phylogeny of the subfamily Bothriodontinae was thoroughly tested in recent studies (e.g. Lihoreau et al., 2015; Lihoreau et al., 2017), the anthracotheres are still in urgent need of a comprehensive revision, particularly concerning the 'waste-basket' genus Anthracotherium and its potential relatives. Such a revision is crucial for the understanding of the origin of anthracotheres, the relationships between cetaceans and hippopotamids, and the dispersal event from Asia to the different continental landmasses hosting Anthracotheriinae at the end of the Eocene.

\section{ABBREVIATIONS}

Institutional abbreviations: NHML, Natural History Museum of London, United Kingdom;
MJSN, JURASSICA Museum, formerly Musée Jurassien des Sciences Naturelles, Switzerland; NMB, Naturhistorisches Museum Basel, Switzerland;NMBE, Naturhistorisches Museum der Burgergemeinde Bern, Switzerland; MHNM, Muséum d'Histoire naturelle de Marseille, France; MHNT, Muséum d'Histoire Naturelle de Toulouse, France; MNHN, Muséum National d'Histoire Naturelle de Paris, France; FSL, collection of the Université Claude Bernard de Lyon, France; and UM, Université de Montpellier, France

Anatomical abbreviations: C/c, upper/lower canine; $\mathrm{I} / \mathrm{i}$, upper/lower incisor; $\mathrm{M} / \mathrm{m}$, upper/lower molar; $\mathrm{P} / \mathrm{p}$, upper/lower premolar; H, height; L, length; W, width.

\section{MATERIAL AND METHODS}

We conducted a systematic review of Anthracotheriinae based on an original phylogenetic hypothesis obtained by cladistic analysis, which was based on comparisons of dental characters of the included taxa (see Supporting Information, Appendices S1 and S2). The complete matrix is available as Supporting Information (Appendix S3). The cladistics analysis was performed with a heuristic search using PAUP 4.0a151 (Swofford, 2002; Supporting Information, Appendix S4). The tooth terminology for anthracotheres follows that of Boisserie et al. (2010), established for all representatives of hippopotamoids, and is illustrated in this paper for a better understanding of the diagnostic characters (Fig. 1).

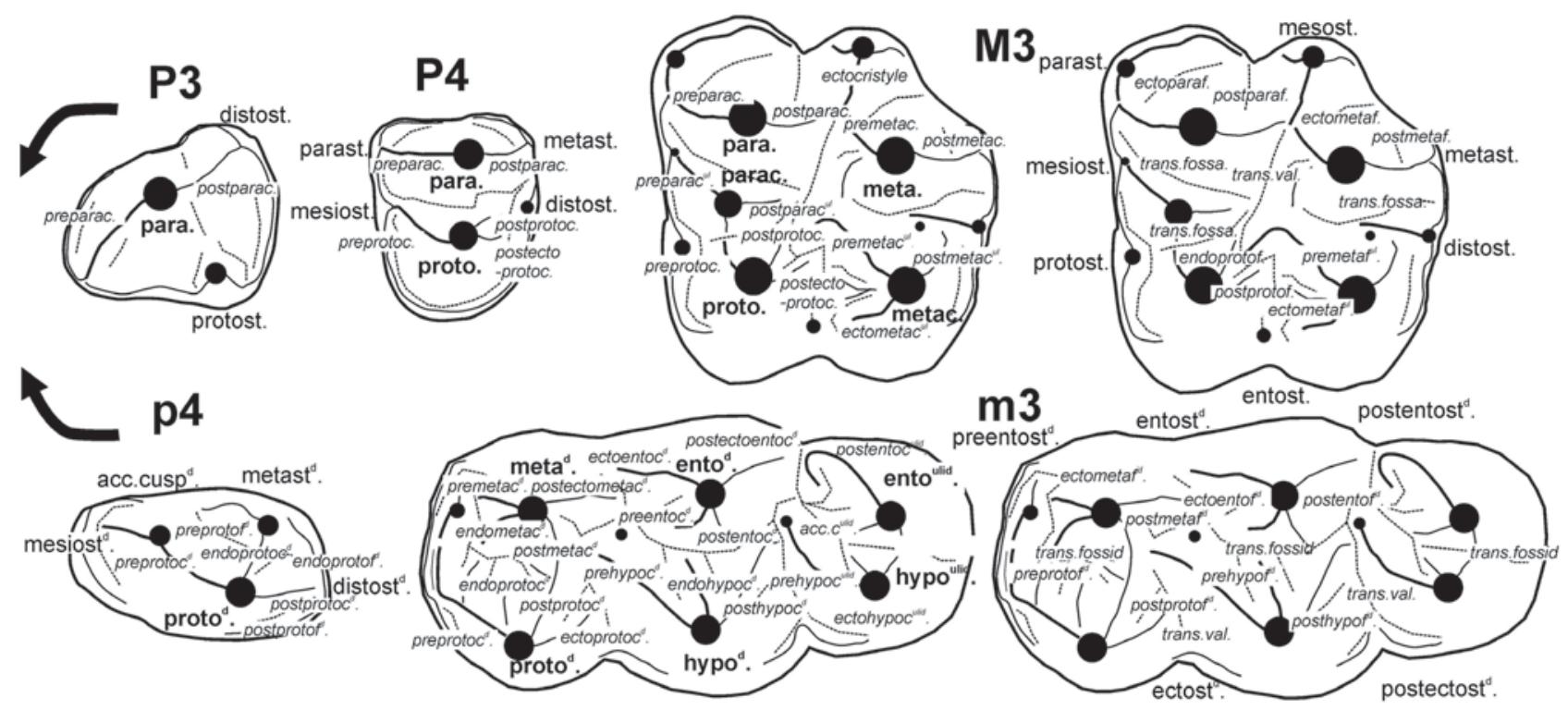

Figure 1. Dental terminology mapped on sketches (not to scale) of upper and lower cheek teeth of Anthracotherium magnum in occlusal views, following Boisserie et al. (2010). Names of the cusps/cuspids are in bold, cristae/cristids and fossae/ fossids in italic and styles/stylids in plain text. Abbreviations: c., crista/cristid; f., fossa/fossid; st., style/stylid; trans. fossa/ fossid, transverse fossa/fossid; trans. val., transverse valley. Black arrows indicate the mesiolingual direction. 


\section{TAXONOMIC SAMPLING}

\section{Outgroup}

We selected the genera Haplobunodon and Choeropotamus as outgroup taxa. They are sometimes considered to belong to two distinct families (Haplobunodontidae and Choeropotamidae, respectively, following Sudre, 1978) or to the same family (Choeropotamidae, according to Gentry \& Hooker, 1988; Hooker \& Thomas, 2001; Erfurt \& Métais, 2007). Lihoreau et al. (2015) suggested that they belong to two different clades. We chose them as our outgroup taxa because their dental patterns are similar to those of anthracotheriid (anthracotheroid like), allowing us to propose dental homologies, and because some choeropotamids have been considered the sister group of anthracotheres in other analyses (Orliac et al., 2010; Lihoreau et al., 2015). The genus Haplobunodon, with the species Haplobunodon lydekkeri Stehlin, 1908 from Hordle, UK and Haplobunodon solodurense Stehlin, 1908 from Egerkingen, Switzerland, was mainly coded based on casts housed at the UM and on information gathered from the literature (Hooker \& Thomas, 2001). The genus Choeropotamus was coded by direct observations on fossils of Choeropotamus depereti Stehlin, 1908 from Euzet, France, Choeropotamus sudrei Casanovas-Cladellas, 1975 from Fons 1, France and Choeropotamus affinis Gervais, 1852 from Mormoiron, France, housed in the UM and the FSL, and completed with data from Sudre (1978).

\section{Ingroup}

The analysis comprised 23 taxa (including samples identified only at the generic level) representing the anthracotheres (details on taxa are in Supporting Information, Appendix S2). We coded Siamotherium, considered as the first generic offshoot of anthracotheres (Ducrocq et al., 2000; Lihoreau \& Ducrocq, 2007; Tsubamoto et al., 2011; Soe et al., 2017) and known since the late Bartonian in South East Asia ( 39-38 Mya for Tsubamoto et al., 2011; or 4140 Mya for Soe et al., 2017). We used Siamotherium krabiense Suteethorn et al., 1988 from the Priabonian in Thailand (Chaimanee et al., 2013), where abundant material is available (Ducrocq, 1999). We chose two branching groups for Anthracotheriinae: the Bothriodontinae, with three species [Bothriogenys orientalis Ducrocq, 1997, Bothriodon velaunum (von Meyer, 1832) and Elomeryx borbonicus (Geais, 1934)], and the Microbunodontinae (two species of Microbunodon and three species of Anthracokeryx). We coded Anthracokeryx birmanicus Pilgrim \& Cotter, 1916, because this taxon was previously synonymized with Anthracotherium by Tsubamoto et al. (2002), and Anthracothema pangan Pilgrim \& Cotter, 1916, sometimes considered an Anthracotherium species
(Ducrocq, 1999). We also included Myaingtherium kenyapotamoides Tsubamoto et al., 2011, which was proposed as an Anthracotheriinae (Tsubamoto et al., 2011; Lihoreau et al., 2015) or as the first anthracothere (Tsubamoto et al., 2011).

We included all three genera that were affiliated with Anthracotheriinae by Lihoreau \& Ducrocq (2007): the Eurasian Anthracotherium, the North American Heptacodon with the species Heptacodon occidentalis Osborn \& Wortman, 1894 and the European Prominatherium dalmatinum (von Meyer, 1854), the only representative of this genus. Lihoreau \& Ducrocq (2007) recognized 15 species within Anthracotherium; Stehlin (1910) was the latest to revise the genus and to discuss many species that emerged during the $19^{\text {th }}$ century. Unfortunately, the erection of numerous species was based on scarce and/or unappropriated material. For example, Anthracotherium alsaticum Cuvier, 1822 was described based on a fragmentary mandible of a juvenile individual (mandible with $\mathrm{dp} 2-\mathrm{m} 1$ ) and consequently, later attributions to this species were difficult (De Blainville, 1848). Filhol (1877) assigned material that was considered to belong to another species, simply mentioning it as A. alsaticum nec Cuvier (Stehlin, 1910; Brunet, 1970). Furthermore, diagnosis of Anthracotherium bumbachense Stehlin, 1910 is based on postcranial elements and attributions to this species of other specimens (mainly dental material) from other localities and is, therefore, dubious. Similar comments can be made for Anthracotherium seckbachense Kinkelin, 1884 and Anthracotherium illyricum Teller, 1886 , for which even the attribution to the genus cannot be confirmed owing to the scarcity of the discovered fossils and/or their poor preservation status. Finally, there have been many attempts to synonymized Anthracotherium valdense Kowalevsky, 1873 with Anthracotherium magnum Cuvier, 1822, the earliest described species of the genus. Therefore, we retained five Anthracotherium species that we consider valid: A. magnum, Anthracotherium hippoideum Rütimeyer, 1857, A. monsvialense, Anthracotherium bugtiense Pilgrim, 1907 and Anthracotherium chaimanei Ducrocq, 1999. Furthermore, we included important additional material of Anthracotherium that could represent valid taxa (Anthracotherium spp. from Bugti Hills, Pakistan and from La Bénissons-Dieu, Mouillac, St Henri and St Menoux, France). The material from St Menoux was previously considered to belong to Anthracotherium cuvieri Gaudry, 1873. However, as this species was erected on material from the lower Miocene in Neuville, France and as its holotype belongs to Brachyodus onoideus (Gervais, 1859), the species is invalid.

We did not include Anthracotherium bimonsvialensemagnum Golpe-Posse, 1972, because it is not distinguishable from $A$. monsvialense by its tooth morphology or dimensions (see Discussion 
on systematic palaeontology), and we excluded Anthracotherium kwablianicum (Gabounia, 1964) from Benara (Georgia), because this species is known only by a few remains. Furthermore, we did not discuss the two Chinese species ascribed to the genus Heothema, because they were considered a junior synonym of Anthracotherium by Ducrocq (1999) and Lihoreau \& Ducrocq (2007), respectively.

\section{CHARACTERS}

We coded 106 dental and mandibular traits, using already published characters (Lihoreau \& Ducrocq, 2007; Boisserie et al., 2010; Orliac et al., 2010; Lihoreau et al., 2015) and 32 new characters (see Supporting Information, Appendix S1). We did not add characters of the enamel microstructure (Alloing-Séguier et al., 2014), because we cannot access material for many key species. There are no cranial characters, because very few cranial remains of Anthracotheriinae exist in accessible collections, limited to some of Heptacodon, a flattened skull of A. chaimanei, a complete skull of Anthracotherium gastaldii Squinabol, 1890 (synonymized with $A$. magnum by Kotsakis, 1984; Ghezzo \& Giusberti, 2016) exposed in Firenze Museum, and a skull from La Bénissons-Dieu (considered as A. bumbachense by Roman \& Boucher, 1936). We did not use postcranial remains, because only a few postcranial bones are clearly attributed to a valid species of Anthracotherium. However, after clear dental attributions, it will be necessary to investigate the postcranial ascriptions for each locality. Indeed, some important characters, such the subisodactyly and the anisodactyly, were used many times to advocate for two distinct Anthracotherium lineages (e.g. Kowalesky, 1873).

\section{RESULTS}

We obtained a matrix of 25 taxa, for which 106 dental character states were coded (Supporting Information, Appendix S3). For the cladistic analysis, we obtained two trees of 363 steps each, with a consistency index (CI) of 0.35 and a retention index (RI) of 0.53 . The low CI is linked to an important homoplasy between the three anthracothere subfamilies. The two trees differed in the position of Heptacodon, considered a sister group to all 'Anthracotherium' s.l. (meaning all species attributed to Anthracotherium before this revision) or proposed to be within an Anthracotherium s.s. clade that includes the type species of the genus (A. magnum) and A. monsvialense, A. bugtiense and A. chaimanei. Siamotherium, Myaingtherium and Anthracothema constitute a stem Hippopotamoidea clade. All previously described subfamilies (Lihoreau \&
Ducrocq, 2007) were confirmed, and Microbunodontinae was grouped in a clade with Bothriodontinae, as has been suggested by others (e.g. Lihoreau \& Ducrocq, 2007; Lihoreau et al., 2015). Below, we describe the consensus tree, including relationships and character state distributions within Anthracotheriinae, with a special focus on eight key nodes (Fig. 2).

\section{Anthracotheriinae s.l.}

This node was supported in all resulting trees, although the Bremer index $(\mathrm{BI})$ was low $(\mathrm{BI}=1)$. This clade includes the genera 'Anthracotherium' s.l., Heptacodon, Prominatherium and the species Anthracokeryx birmanicus. The latter differs from other Anthracokeryx species (Anthracokeryx tenuis Pilgrim \& Cotter, 1916 and Anthracokeryx thailandicus Ducrocq, 1999), which are considered Microbunodontinae (sister group of Microbunodon genus) in the present study, in having, on the lower molars, a fully developed postectoprotocristid $\left(17^{1}\right)$, a postprotofossid $\left(18^{1}\right)$, an ectoprotofossid (19 $)$, a prehypocristid divided into two mesial arms $\left(29^{\circ}\right)$, a posthypofossid $\left(35^{1}\right)$, an endohypocristulid on $\mathrm{m} 3\left(46^{\circ}\right)$, and on the upper molars a secondary cristule labial to the metaconule $\left(56^{1}\right)$, a distostyle positioned at the level of the metaconule $\left(57^{\circ}\right)$ and a postparafossa on P3 $\left(95^{\circ}\right)$. Tsubamoto et al. (2002) already proposed inclusion of this species in Anthracotherium. Our phylogenetic results suggest that $A$. birmanicus is not an Anthracotherium, but represents an early taxon of Anthracotheriinae or its sister group. As Anthracokeryx birmanicus is the type species of the genus, we propose to assign $A$. tenuis and $A$. thailandicus to a new genus. However, a complete analysis of the genus Anthracokeryx is necessary before a generic reattribution of these microbunodontine species is possible.

Three non-ambiguous features characterized Anthracotheriinae (including A. birmanicus) in our phylogeny. These are one synapomorphy, the important development of crown height of the lower canine (77'), and two homoplasies, the presence of an accessory cristulid issued from the hypoconulid and mesially directed between the pre- and the posthypocristulid on m3 $\left(46^{1}\right)$ and the presence of a secondary cristule labial to the metaconule on the upper molars $\left(56^{1}\right)$. The two latter characters are also present in Anthracothema pangan and are mostly lacking within the clade 'Anthracotherium' s.l.

\section{Anthracotheriinae s.s.}

The clade including 'Anthracotherium' s.l., Heptacodon and Prominatherium corresponds to the subfamily Anthracotheriinae as defined by Lihoreau \& Ducrocq (2007). This node is well supported by 17 character features and a Bremer index of 2. Five non-ambiguous character states define this node: the presence of a postectoprotocrista on the molars $\left(49^{1}\right.$, convergent 


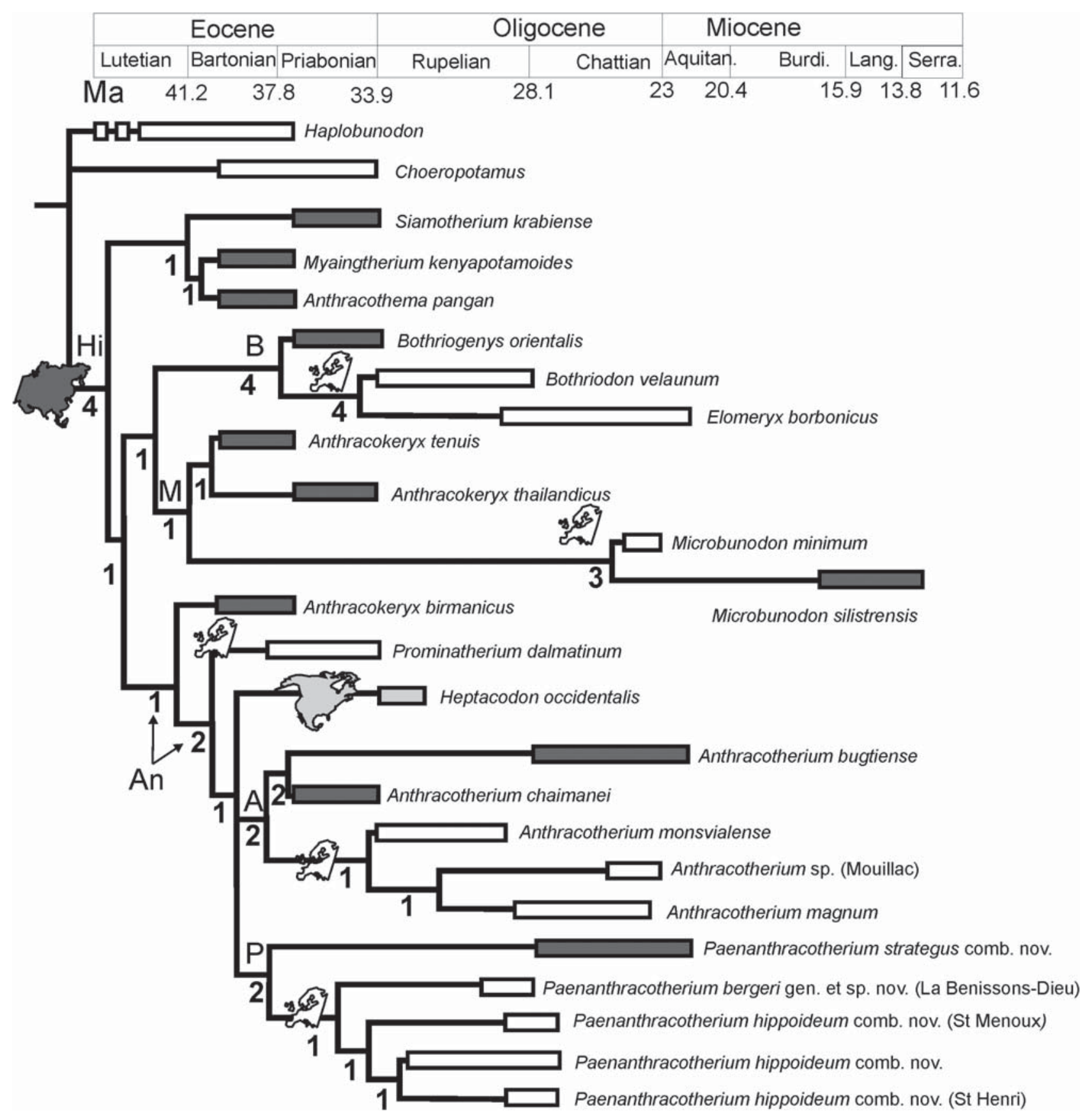

Figure 2. Phylogenetic relationships obtained from the cladistic analysis of the Anthracotheriinae. Strict consensus tree of the two most parsimonious trees (363 steps, consistency index $=0.35$, retention index $=0.53$ ). Abbreviations: A, Anthracotherium; An, Anthracotheriinae; Aquitan., Aquitanian; B, Bothriodontinae; Burdi., Burdigalian; Hi, Hippopotamoidea; Lang., Langhian; M, Microbunodontinae; P, Paenanthracotherium gen. nov.; Serra., Serravalian. Values below the branches are Bremer supports. Asian taxa are shown in dark grey, American taxa in light grey and European taxa in white.

with basal Anthracotheriidae and Bothriodontinae); the presence of a mesiolingual style (= protostyle) on the upper molar mesial cingulum $\left(66^{1}\right.$, convergent with first anthracothere offshoot); the parastyle larger than the mesostyle, which is a basal condition in
Anthracotheriinae if we exclude A. birmanicus $\left(68^{2}\right)$; a fully developed metastyle $\left(70^{1}\right)$, also present in derived bothriodontines and derived microbunodontines; and the presence of a postprotocrista on $\mathrm{P} 4$ that joins the distostyle as in some Bothriodontinae (here, 
B. velaunum, $\left.99^{1}\right)$. Other traits show ambiguous positions, notably owing to the lack of material for the genus Prominatherium, such as the presence of a lingual cingulid on $\mathrm{p} 4\left(13^{1}\right)$, the presence of a postentocristid on $\mathrm{m} 3\left(44^{\circ}\right)$ and on $\mathrm{m} 1-\mathrm{m} 2\left(28^{1}\right)$ also in bothriodontines, the bone fusion at the symphysis in the adult specimen $\left(74^{1}\right)$ convergent with some taxa in other subfamilies, and the presence of an ectoparafossa on P2 and/or P3 $\left(94^{1}\right)$. When Prominatherium is removed from the analysis, ten non-ambiguous traits support this node.

\section{Anthracotherium clade}

This clade contains some species of the genus 'Anthracotherium' s.s., including the type species, A. magnum. Anthracotherium is defined by seven non-ambiguous traits. Four of them are convergent with $A$. birmanicus: a postectoprotocristid on lower molars fully developed or reduced in the valley (171); a postprotofossid on lower molars (181); the prehypocristid divided into two mesial arms on lower molars $\left(29^{\circ}\right)$; and the presence of a posthypofossid on the lower molars $\left(35^{1}\right)$. The presence of an entoconulid on m3 (42 $)$ is also observed in Myaingtherium and on some specimens of $A$. pangan and Elomeryx crispus (Gervais, 1849). Some characters appear as reversions within Anthracotheriinae: the lack of an accessory cristulid issued from the hypoconulid and mesially directed between the pre- and the posthypocristulid on m3 $\left(46^{1}\right)$; and parastyle smaller or equal to mesostyle $\left(68^{1}\right)$. The presence of an endometacrista on the upper molar $\left(60^{1}\right)$ is convergent with stem Hippopotamoidea and the material of 'Anthracotherium' from St Henri.

\section{European Anthracotherium}

This clade includes European species belonging to the Anthracotherium clade (A. monsvialense, A. magnum and Anthracotherium from Mouillac) and is defined by three non-ambiguous characters: the presence of an ectoprotofossid on lower molars $\left(19^{1}\right)$ convergent with A. birmanicus, Microbunodon silistrensis (Pentland, 1828), B. orientalis and $A$. pangan, but unique within the clade Anthracotherium; the presence of a well-individualized postectoentocristid on lower molars $\left(26^{2}\right)$ convergent with some bothriodontines; and a strong and continuous cingulum on P4 (104 $)$ convergent with Microbunodon and Elomeryx. The material from Mouillac must be considered closely related to $A$. magnum and eventually belonging to the same species (see Discussion for systematic palaeontology) on the basis of three shared characters, including frequent presence of an ectoprotofossid on p4 (12 $)$, also known in Siamotherium, cristulids of the hypoconulid on $\mathrm{m} 3$ that tend to join together and not keep parallel $\left(22^{\circ}\right)$, only convergent with A. chaimanei within Hippopotamoidea, and entostyle on the upper molars not fully developed in style but rather a cingulum (671), unique within Anthracotherium.

\section{Asian Anthracotherium}

This clade includes the Asian species in the Anthracotherium clade (A. chaimanei and A. bugtiense), which is defined by three non-ambiguous traits, including an apomorphy, namely the presence of an entostylid on lower molars $\left(36^{1}\right)$, and two homoplasies, namely the lingual cingulid on $\mathrm{p} 4$ that never joins the mesiolingual cristid nor the entostylid $\left(13^{\circ}\right)$, considered here as a reversion, and the strong development of a distostyle on p4 (103 $\left.{ }^{1}\right)$ convergent with another clade of 'Anthracotherium' that we name 'selenodont Anthracotherium' and some bothriodontines.

\section{'Selenodont Anthracotherium' clade}

This clade includes A. hippoideum and four 'Anthracotherium' s.l. collections: specimens from St Menoux previously attributed to $A$. cuvieri, the material from La Bénissons-Dieu and from St Henri (wrongly attributed to A. bumbachense; Roman \& Boucher, 1936), and part of the Anthracotherium specimens from Bugti. Those specimens and A. hippoideum are definitively different from any species in the Anthracotherium clade (as defined above) and can be regarded as a different genus (see Discussion for systematic palaeontology). We identified this new genus on the basis of five non-ambiguous traits: lack of connection between premetacristid and preprotocristid on lower molars $\left(16^{1}\right)$ convergent with A. bugtiense and $A$. tenuis; lack of a clear endometacristid on lower molars $\left(21^{\circ}\right)$; the main arm of prehypocristid that connects postmetafossid $\left(32^{1}\right)$ convergent with some bothriodontine; the pinched ribs of labial cusps of the upper molars (48 $)$; and the lack of secondary cristule labial to the metaconule $\left(56^{\circ}\right)$, unique within anthracotheriines.

\section{European 'selenodont Anthracotherium'}

Our results allow the discrimination of a clade with a low Bremer index (1), characterized by five nonambiguous traits: the posthypocristid on $\mathrm{m} 1-\mathrm{m} 2$ that joins the postentocristid $\left(33^{1}\right)$, which is convergent with Heptacodon, Anthracotherium from Mouillac and early bothriodontines; the lack of protocone and metaconule junction on M1-M2 $\left(52^{\circ}\right)$ convergent with $A$. birmanicus and $B$. velaunum; the postparacristule that extends to protocristae and closes the transverse valley $\left(59^{\circ}\right)$ convergent with Heptacodon, A. tenuis and Myaingtherium within hippopotamoids; the postmetacrista that labially connects the metastyle $\left(65^{1}\right)$ convergent with Heptacodon and some bothriodontines and may indicate a further selenodonty; and the strong development of a distostyle on P4 $\left(103^{1}\right)$ convergent with Asian Anthracotherium and somes bothriodontines. 
Within the European clade of 'selenodont Anthracotherium', we observe that A. hippoideum gathers with the specimens from St Henri and that material from St Menoux is the sister group of this clade. Therefore, we propose that these should be included within one species (see Discussion for systematic palaeontology), which has three non-ambiguous characters: the prehypocristid not inflated (not salient when unworn) in the transverse valley of the lower molars $\left(30^{\circ}\right)$, which appears here as a reversion within Anthracotheriinae s.l. (considering A. birmanicus and Heptacodon); the premetacristule not divided into two mesial arms $\left(53^{\circ}\right)$ convergent with Heptacodon within anthracotheriines; and the presence of a c-p/1 diastema $\left(85^{1}\right)$, unique within anthracotheriines.

\section{DISCUSSION}

\section{TOWARDS A DEFINITION OF THE ANTHRACOTHERIINAE}

When Gill (1872) proposed the first anthracotheriid subfamilies (Anthracotheriinae and Hyopotaminae), he based his subdivision on the molarization of P4. Subsequently, owing to many synonymies and discoveries of new genera, Scott (1940) proposed the redefinition of Anthracotheriinae as exclusively Old World anthracotheres with pyramidal cusps on the upper molars. MacDonald (1956) rejected subfamilies, because he considered Heptacodon to be misplaced within Bothriodontinae (derived from the Hyopotaminae concept of Gill, 1872), and suggested a complete review of the genera before introducing subfamilial groupings. Viret (1961) accepted the concept of Anthracotheriinae but included numerous Eocene genera from Europe that do not belong to Anthracotheriidae (e.g. Lophiobunodon, Raghatherium). He proposed the definition of Anthracotheriinae based on brachybunodont molars with conical to subpyramidal cusps, large spadeshaped incisors, small canines that can develop into strong tusks, and few and small diastema. He also included many of the Old World genera: Anthracothema, Anthracokeryx, Anthracotherium and Microbunodon. Kron \& Manning (1998) proposed the definition of Anthracotheriinae based on North American anthracotheres. Thus, they included the genus Heptacodon (following McDonald, 1956) in this subfamily and proposed the following definition: transverse valley in upper molar extending, at most, only part way into the mesostyle, so that the mesostyle is cuspate to partially cuspate in shape, and hypoconulid prominent on m1-2. Lihoreau \& Ducrocq (2007) discussed anthracotheriid subfamilies most recently and they not only proposed the Microbunodontinae subfamily (Microbunodon and
Anthracokeryx) based on a cladistic analysis of several anthracotheriid genera, but also reviewed the definition of Anthracotheriinae. They pointed out the following characters for Anthracotheriinae: upper molars with an accessory cusp (= protostyle) on the mesial cingulum, rather bunodont cheek teeth compared with other subfamilies, a strong vertical lower canine with a circular section and a distal wear facet, no diastema between the lower canine and $\mathrm{p} 1$, and a symphysis with an elliptical cross-section. They included the genera Anthracotherium, Heptacodon and Prominatherium in the subfamily.

The phylogenetic results of the present study allow two hypotheses for the definition of Anthracotheriinae, including or excluding Anthracokeryx birmanicus. For both scenarios, it excludes the genera Siamotherium, Myaingtherium and Anthracothema, considering these taxa as the first offshoots of Hippopotamoidea. Myaingtherium was included in Anthracotheriinae by Lihoreau et al. (2015), but Anthracotheriinae was not as comprehensively included in their study as in this one. As a result of the new definition of Anthracotherium, Anthracothema is valid here, unlike the definitions by Ducrocq (1999), Tsubamoto et al. (2002) and Lihoreau \& Ducrocq (2007). In the present study, we consider that Anthracotherium is not present in the Pondaung formation and restrain its occurrence to the latest Eocene of Thailand and to the Oligocene deposits of Europe and Pakistan. Tsubamoto et al. (2002) assigned the genotype Anthracokeryx birmanicus to Anthracotherium and consequentially to Anthracotheriinae. Other species of Anthracokeryx (A. thailandicus and A. tenuis) were included in Microbunodontinae (Lihoreau \& Ducrocq, 2007), but the phylogenetic position of the type species was not tested. Our phylogenetic results suggest that A. birmanicus is not an Anthracotherium (the genus being restricted), but may represent either an early taxon of Anthracotheriinae, or its sister taxon. Therefore, we propose keeping $A$. birmanicus as the genotype and considering $A$. tenuis and $A$. thailandicus as belonging to a new genus. As mentioned earlier, this particular systematic discussion is not the purpose of the present paper and should be the subject of its own study.

Following the first hypothesis (including A. birmanicus in Anthracotheriinae s.l.), the subfamily will be defined by the development of crown height of the lower canine, the presence of an accessory cristulid issued from the hypoconulid and mesially directed between the preand the posthypocristulid on $\mathrm{m} 3$, and the presence of a secondary cristule labial to the metaconule on the upper molars. The two latter characters are also present in A. pangan and are lacking within the clade Anthracotherium + 'selenodont Anthracotherium'.

The second hypothesis (A. birmanicus not included in Anthracotheriinaes.s.)ismorerobustandissupportedby 
17 character features. However, the few known remains of Prominatherium cause numerous uncertainties in the character expressions of this node and reduce the importance of the support for the clade Heptacodon + Anthracotherium + 'selenodont Anthracotherium'. Anthracotheriinae can thus be defined (excluding ambiguous characters) by the presence of postectoprotocrista on molars $\left(49^{1}\right)$, the presence of a mesiolingual style (= protostyle) on the mesial cingulum of the upper molars $\left(66^{1}\right)$, the parastyle larger than the mesostyle $\left(68^{2}\right)$, a fully developed metastyle $\left(70^{1}\right)$, and the presence of a postprotocrista on $\mathrm{P} 4$ that joins the distostyle $\left(99^{1}\right)$. In this second hypothesis, some of these traits are recognized in a previous subfamily diagnosis (Lihoreau \& Ducrocq, 2007), such as the protostyle on the upper molars $\left(66^{1}\right)$. Therefore, it currently seems that the exclusion of $A$. birmanicus from Anthracotheriinae allows for a more robust definition of the subfamily. Further analysis of 'Anthracokeryx' will allow clarification of the position of A. birmanicus as a stem Anthracotheriinae and allow the new generic attribution of 'Anthracokeryx' species to be related more closely to microbunodontines.

\section{REASSESSMENT AND SPLITTING OF THE GENUS ANTHRACOTHERIUM}

Anthracotherium has not been reviewed for a long time; since Cuvier (1822) too many species have been introduced, sometimes from abundant material [e.g. A. magnum from Cadibona (De Blainville, 1848), A. monsvialense from Monteviale (for review, see Ghezzo \& Giusberti, 2016), A. cuvieri from St Menoux (Gaudry, 1873)] and sometimes with scarce and irrelevant remains [a mandible with deciduous teeth for A. alsaticum from Lobsann (Cuvier, 1822); an isolated talus for A. seckbachense from Seckbach (Kinkelin, 1884)]. Fischer-Ooster (1861) and Gaudry (1873) proposed the first reviews of the history of the genus, but it was Kowalesky (1873) who introduced the initial main division of Anthracotherium into two groups: the anisodactyls with reduced lateral digits and the subisodactyls with four sub-equal digits. Stehlin (1910) tried to simplify the systematics of Anthracotherium by proposing many synonymies. However, in the same study he created a new species based on scarce postcranial material and much worn teeth (A. bumbachense from Bumbach). The latest review of the genus was by Sieber (1935), who accepted the validity of all species of Anthracotherium. He proposed grouping of the species in four clades, considering size of the teeth and metapodial proportions. Based on our knowledge, this is the most recent review of Anthracotherium, despite recent descriptions of new species, such as A. bimonsvialensemagnum from the lower Oligocene in Montalban, Spain and A. chaimanei from the Late Eocene in Krabi (Wai Lek Mine), Thailand. Therefore, the present study is the first to conduct a systematic revision of European Anthracotherium in 80 years. The cladistic analysis results in a phylogenetic hypothesis that shows two distinct clades of 'Anthracotherium' s.l. Considering the abundance of newly described species within this genus, the robust dental differences between the two clades, and the palaeobiogeographical and stratigraphic distribution, this split represents important progress in the systematics of Anthracotheriinae.

The type species $A$. magnum (including the material from Mouillac), A. monsvialense, A. bugtiense and A. chaimanei gather in a clade that should correspond to Anthracotherium (see below for emended diagnosis). The specimens from St Menoux, A. hippoideum, the material from La Bénissons-Dieu and from St Henri and part of the specimens of Anthracotherium from Bugti can be regarded as a different, new genus. Moreover, within this clade, we identified material not assigned to a species and, thus, additionally propose a new species with the material from La Bénissons-Dieu and Digoin, Vendèze, Le Garouillas, La Comberatière, Moissac, Lamontgie and Petrosani (see below for Paenanthracotherium bergeri gen. nov., sp. nov.).

Class Mammalia Linnaeus, 1758

ORDER ARTIODACTYLA OWEN, 1848

SUPERFAMILY HiPPOPOTAMOIDEA GRAY, 1821

(SENSU GENTRY \& HOOKER, 1988)

SUBFAMILY ANTHRACOTHERIINAE LEIDY, 1869

Genus PAENANTHRACOTHERIUM GEN. NOV.

urn:lsid:zoobank.org:act:2AC7A5A3-A894-45A6-AED100A17C4EF2D

\section{Diagnosis (Fig. 3)}

Medium to large Anthracotheriinae s.l. (Fig. 4) with rather selenodont cheek teeth, p3 with entostylid $\left(6^{1}\right)$, lower molars that lack clear endometacristid $\left(21^{\circ}\right)$ and with main arm of the prehypocristid connecting to the postmetafossid ( $\left.32^{1}\right)$, P3 without distolingual cingular style $\left(91^{\circ}\right)$ and without ectoparacrista $\left(93^{\circ}\right)$, upper molars with labial cusps with pinched ribs $\left(48^{1}\right)$ and without secondary cristules labial to metaconule $\left(56^{0}\right)$.

\section{Differential diagnosis (Fig. 3)}

Paenanthracotherium differs from all Anthracotheriinae s.l. by the absence of or reduced endometacristid on the lower molars $\left(21^{\circ}\right)$ and the pinched mesiodistal development of the ribs of labial cusps on the upper molars $\left(48^{1}\right)$. Within Anthracotheriinae s.l., Paenanthracotherium differs from Heptacodon and A. birmanicus by a mesiolingual secondary cristid on $\mathrm{p} 4$, connecting 


\section{P3 P4 \\ M3 \\ p3 \\ p4 \\ m3}
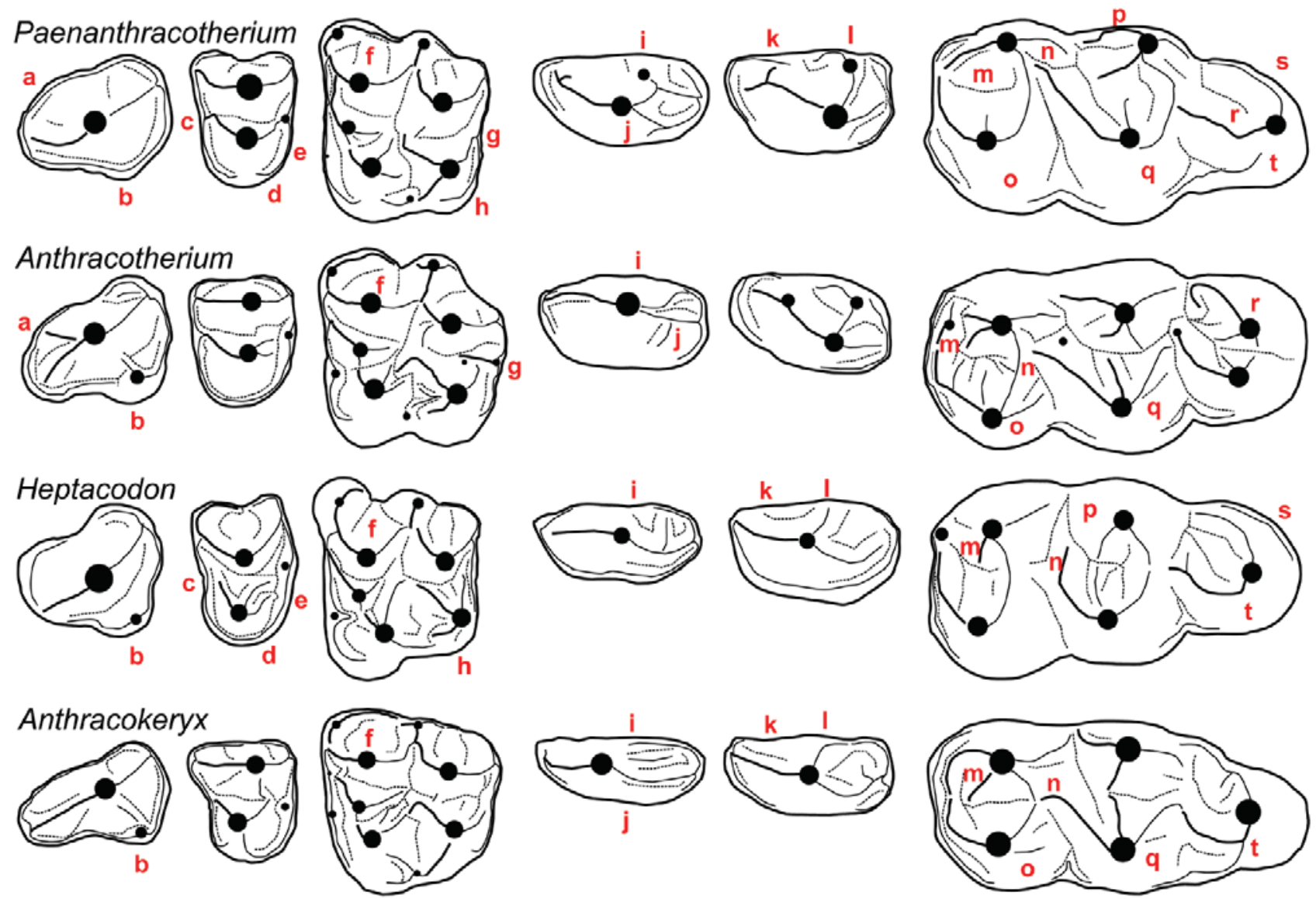

\section{Prominatherium}
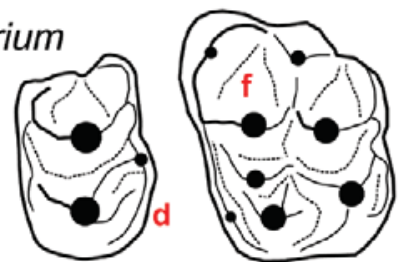

Figure 3. Schemes of Anthracotheriinae cheek teeth illustrating 20 dental diagnostic characters of Paenanthracotherium gen. nov. compared with other genera of the subfamily. The corresponding characters from the Supporting Information (Appendix S1) are in brackets. Abbreviations: a, P3 without ectoparacrista (930); b, P3 without distolingual cingular style $\left(91^{\circ}\right)$; c, the preprotocrista on P4 joins the base of the paracone then the mesiostyle $\left(100^{\circ}\right)$; d, lack of postectoprotocrista on P4 (1010); e, lack of postprotofossa on P4 (106 $)$; f, pinched ribs of labial cusps of upper molars (48 $\left.{ }^{1}\right)$; g, upper molars without secondary cristules labial to metaconule $\left(56^{\circ}\right)$; h, lack of secondary ectometafossule lingual to ectometacristule $\left(58^{\circ}\right)$; i, p3 with entostylid $\left(6^{1}\right)$; $\mathrm{j}$, the distolabial orientation of the postprotocristid on p3 $\left(2^{2}\right) ; \mathrm{k}$, a mesiolingual secondary cristid on p4 $\left(8^{1}\right)$; 1 , an entostylid on $\mathrm{p} 4\left(11^{1}\right)$; $\mathrm{m}$, lack of clear endometacristid on lower molars $\left(21^{0}\right)$; n, main arm of the prehypocristid connecting the postmetafossid on lower molars $\left(32^{1}\right)$; o, the lack of postectoprotocristid and postprotofossid on lower molars $\left(17^{0}\right.$ and $\left.18^{\circ}\right) ; \mathrm{p}$, an ectoentocristid on lower molars $\left(27^{\circ}\right)$; q, lack of posthypofossid on lower molars $\left(35^{0}\right)$; r, the lack of entoconulid on $\mathrm{m} 3\left(42^{0}\right)$; s, no distal cingulid on $\mathrm{m} 3\left(45^{\circ}\right)$; t, an incomplete but present ectohypocristulid on m3 $\left(39^{1}\right)$.

the preprotocristid with the lingual margin $\left(8^{1}\right)$, an entostylid on $\mathrm{p} 4\left(11^{1}\right)$, an incomplete but present ectohypocristulid on $\mathrm{m} 3\left(39^{1}\right.$; absent in Heptacodon and complete in $A$. birmanicus) and no cristids on the lower canine $\left(80^{\circ}\right)$. It differs from Heptacodon and Prominatherium by the lack of postectoprotocrista on P4 $\left(101^{\circ}\right)$. Moreover, it differs from Heptacodon by lower molars with an ectoentocristid $\left(27^{\circ}\right)$, no distal cingulid on $\mathrm{m} 3\left(45^{\circ}\right)$, no secondary ectometafossule lingual to the ectometacristule $\left(58^{\circ}\right)$, unfused lingual roots of the upper molars $\left(71^{\circ}\right)$, presence of a diastema between $\mathrm{p} 1$ and $\mathrm{p} 2\left(86^{1}\right), \mathrm{P} 1$ and P2 $\left(89^{1}\right)$ and P2 

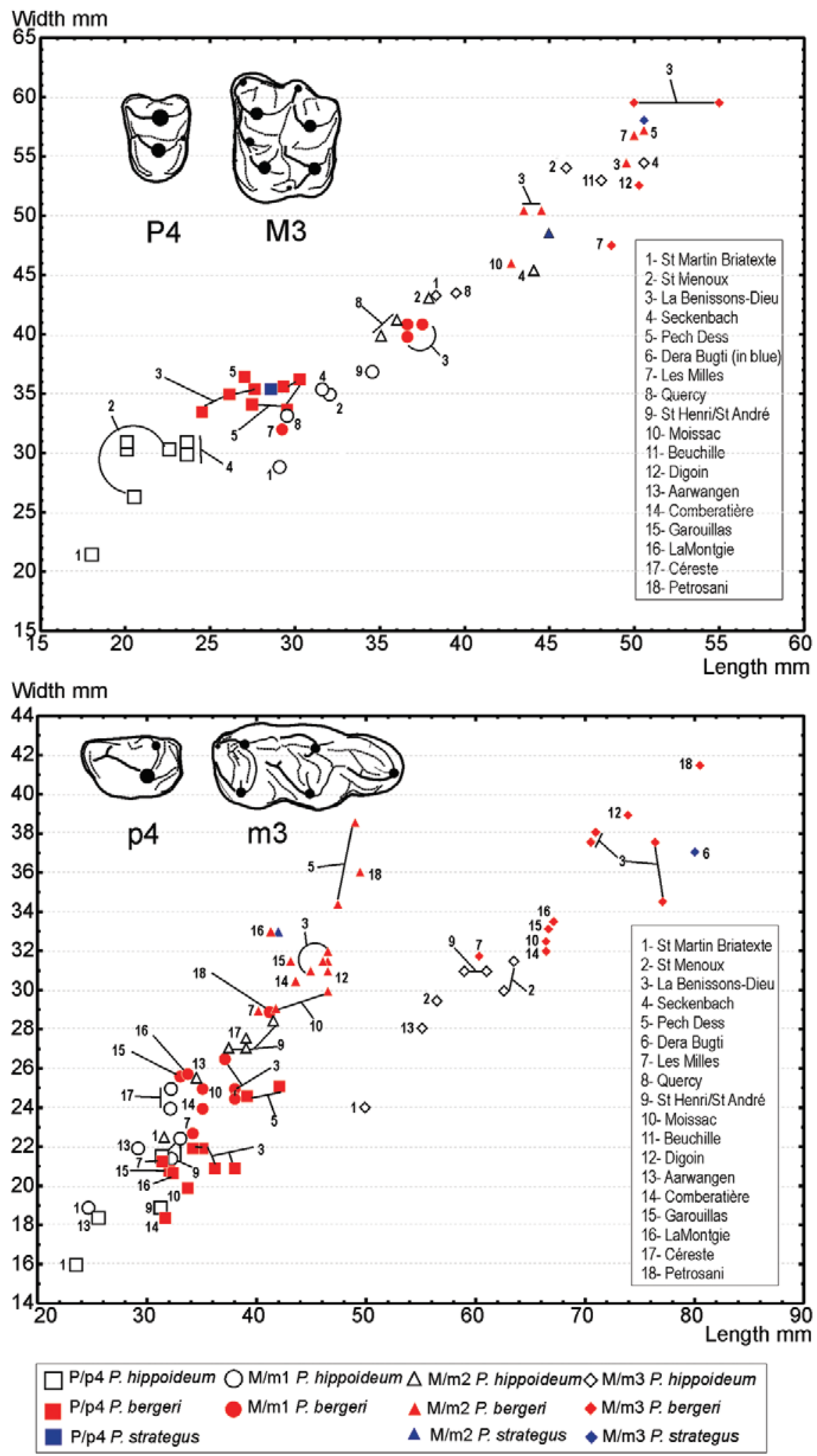

Figure 4. Length and width of upper and lower molars (M/m1, M/m2 and M/m3) and premolars (P/p4) of the three species of Paenanthracotherium gen. nov., namely Paenanthracotherium bergeri sp. nov., Paenanthracotherium hippoideum comb. nov. and Paenanthracotherium strategus comb. nov. (in millimetres). Numbers indicate the localities from which the different specimens came. 
and P3 $\left(90^{1}\right)$, no postprotofossa on P4 $\left(106^{\circ}\right)$, and by the preprotocrista on $\mathrm{P} 4$ that joins the base of the paracone then the mesiostyle $\left(100^{\circ}\right)$. It differs from Anthracotherium and A. birmanicus by the distolabial orientation of the postprotocristid on p3 $\left(2^{2}\right)$, the lack of postectoprotocristid $\left(17^{\circ}\right)$, postprotofossid $\left(18^{\circ}\right)$ and posthypofossid on lower molars $\left(35^{\circ}\right)$, and a unique prehypocristid, not divided into two mesial arms $\left(29^{1}\right)$. It differs from Anthracotherium by the lack of entoconulid on $\mathrm{m} 3\left(42^{\circ}\right)$.

\section{Type species}

Paenanthracotherium bergeri sp. nov. from La Bénissons-Dieu (France), late Early Oligocene.

\section{Other included species}

Paenanthracotherium hippoideum (Rütimeyer, 1857); Paenanthracotherium strategus (Forster-Cooper, 1913).

\section{Etymology}

From the Latin adverb 'paene', meaning almost, and the genus name Anthracotherium Cuvier, 1822, meaning charcoal beast in Latin, in reference to the similarities between both genera and to the inclusion of this genus within Anthracotherium for at least 165 years.

\section{Distribution}

Late Early to Late Oligocene in France, Switzerland, Germany, Romania and Pakistan (e.g. Roman \& Boucher, 1936; Pickford, 1987; Sudre, 1995; Scherler, 2011; Scherler et al., 2013; see Supporting Information, Appendix S5 for a more exhaustive list of localities with references).

\section{Remark on the included species}

Paenanthracotherium hippoideum and P. strategus were previously assigned to the genera Anthracotherium and Brachyodus, respectively (Rütimeyer, 1857; Forster-Cooper, 1913). However, their similar morphology and the inferred phylogeny allow us to gather them in a new genus. The specimens from St Menoux and St Henri, France were attributed to A. cuvieri by Gaudry (1873) and A. bumbachense by Roman \& Boucher (1936). Nevertheless, the morphology of the m3 lacking the entoconulid, the general shape of the teeth, and the dimensions similar to those of P. hippoideum from Aarwangen, Switzerland (Fig. 4) allow us to attribute this material to A. bumbachense.

\section{PAENANTHRACOTHERIUM BERGERI SP. NOV.}

$$
\text { (FIGS 5-7) }
$$

urn:lsid:zoobank.org:act:81139BAC-A379-41DC-A9AB9FD12BB5B20A

Anthracotherium magnum Cuvier from Auvergne; De Blainville, 1848: 126, 129, 131, 133, pl. 'A. magnum, systême dentaire: d'Auvergne' [viewed].
Anthracotherium magnum Cuvier from Moyssac; De Blainville, 1848: 127, pl. 'A. magnum, systême dentaire: du Tarn et Garonne'.

Anthracotherium magnum Cuvier from Digoin; De Blainville, 1848: 127, 129, 130, pl. 'A. magnum, systême dentaire: de Digoin' [viewed].

Anthracotherium magnum Cuvier; Leymerie, 1851: 388-392 [viewed].

'Un Anthracotherium different de Anthracotherium magnum'; Gervais, 1852: 97 [viewed].

Anthracotherium magnum Cuvier; Rütimeyer, 1857: 29.

Anthracotherium Cuvier; Kowalevsky, 1873: pl. 11, figs 37, 52-54, pl. 14, fig. 96.

Anthracotherium bumbachense; Stehlin, 1910: 168-169.

Anthracotherium cf. bumbachense Stehlin; Depéret, 1913: 350-351 [viewed].

Anthracotherium bumbachense * Stehlin; Roman \& Boucher, 1936: 10-38, figs 2-5, 9, 11.2, 13, pl. 1-4 [*holotype, viewed].

'Anthracotherium jeune de St-Henri'; Roman \& Boucher, 1936: fig. 7 [viewed].

Anthracotherium Cuvier; Lavocat, 1951: 130 [viewed in part].

Anthracotherium cuvieri Gaudry; Brunet \& VianeyLiaud, 1987: 31 [viewed].

Anthracotherium bumbachense Stehlin; Brunet \& Vianey-Liaud, 1987: 31 [viewed].

Anthracotherium magnum Cuvier; Sudre, 1995: 214216 [viewed].

Anthracotherium bumbachense Stehlin; Sudre, 1995: 216 [viewed].

Anthracotherium cf. magnum; BiochroM'97, 1997: 791 [viewed].

Anthracotherium bumbachense Stehlin; Hugueney, 1997: 420, table 4 [viewed].

Anthracotherium magnum Cuvier; Hugueney, 1997: 420 [viewed].

Anthracotherium sp.; Becker et al., 2004: 6-7 [viewed]. Elliotherium murphyi nomen nudum; Scherler, 2011: 85-93, figs 5.2, 5.5, 5.6, 5.10, table 5.1 [viewed].

Anthracotherium bumbachense Stehlin; AlloingSéguier et al., 2014: 670-671, 678, table 2 [viewed].

Elliotherium murphyi nomen nudum; Pickford, 2016: 249 [viewed].

\section{Differential diagnosis}

Large Paenanthracotherium (Fig. 4), differing from other species of the genus by the presence of an ectometafossid on the lower molars $\left(20^{\circ}\right)$, a shallow and constant cingulid in front of the transverse valley of the lower molars $\left(37^{1}\right)$, and sometimes the presence of an ectocristylid (381), a less prominent parastyle $\left(68^{1}\right)$, a very small metastyle on the upper molars $\left(70^{\circ}\right)$, and a division into two of the postprotocrista on $\mathrm{P} 4\left(105^{1}\right)$. 

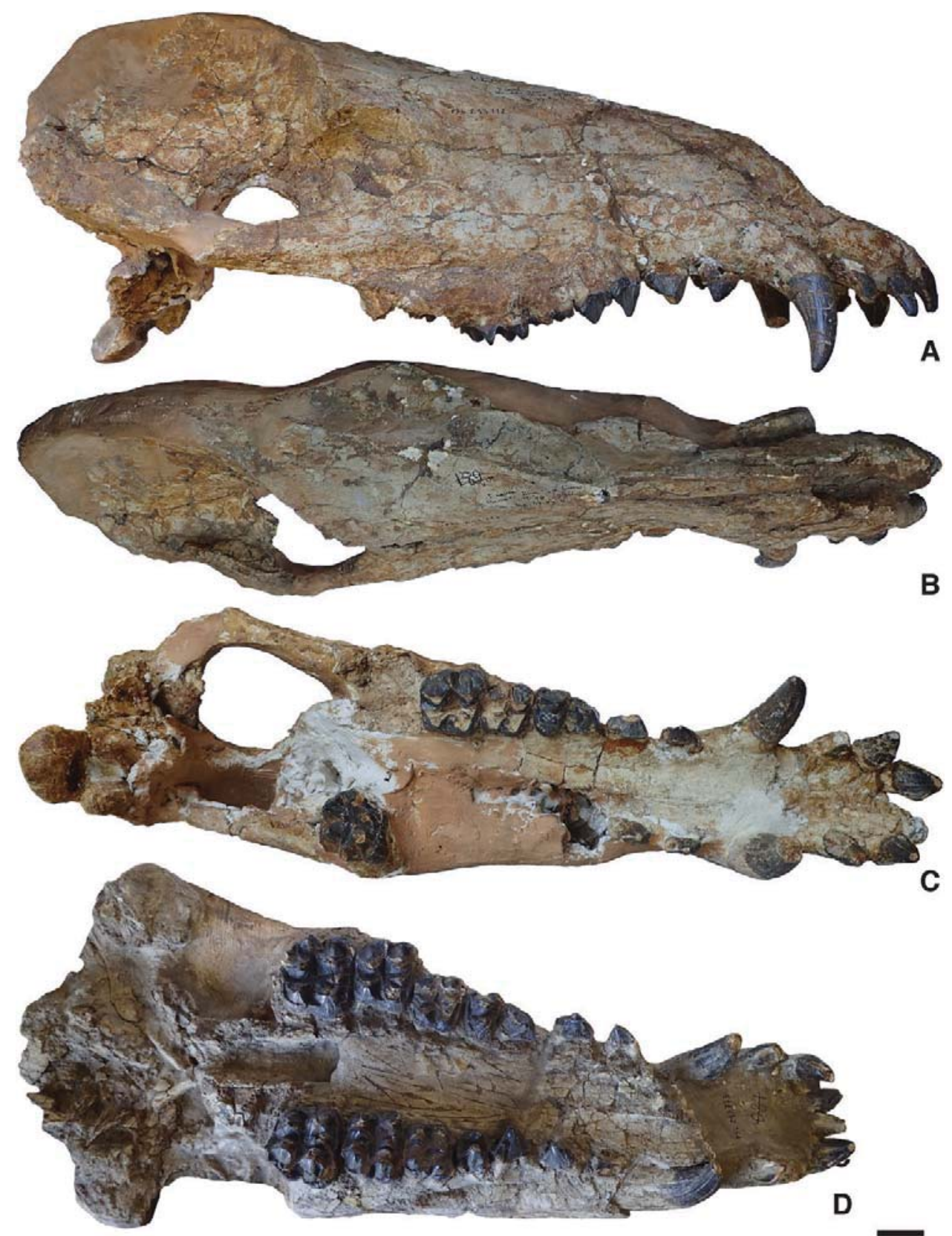

Figure 5. Cranial remains of Paenanthracotherium bergeri gen. nov., sp. nov. from La Bénissons-Dieu, France. A-C, skull (FSL-213772, holotype) in lateral, dorsal and ventral views. D, complete maxilla (FSL-213773, paratype) in basal view. Scale bar: $5 \mathrm{~cm}$.

Paenanthracotherium bergeri differs from $P$. strategus in having the posthypocristid on $\mathrm{m} 1$ and $\mathrm{m} 2$ joining the postentocristid $\left(33^{1}\right)$, no clear junction between the protocone and the metaconule on M1 and M2 $\left(52^{\circ}\right)$, no extension of the postparacristule in the transverse valley $\left(59^{\circ}\right)$, the postmetacrista connecting labially to the metastyle $\left(65^{1}\right)$, and a strong development of the distostyle on $\mathrm{P} 4\left(103^{1}\right)$. Paenanthracotherium bergeri differs from $P$. hippoideum in having a larger size (Fig. 4), a distolingual cingulid on p4 forming a continuous wall until the distostylid $\left(7^{\circ}\right)$, a strong premetacristid on the lower molars $\left(15^{0}\right)$, a lack of connection between the premetacristid and the preprotocristid on the lower molars $\left(16^{1}\right)$, a slightly inflated prehypocristid $\left(30^{1}\right)$, an endohypocristid on the lower molars $\left(34^{1}\right)$, the presence of a unique accessory 


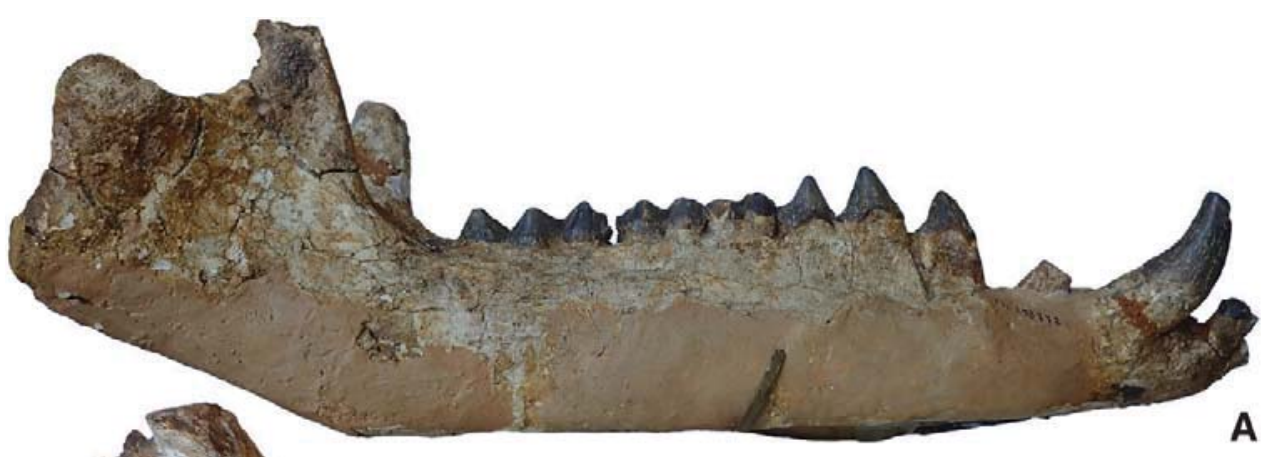

A
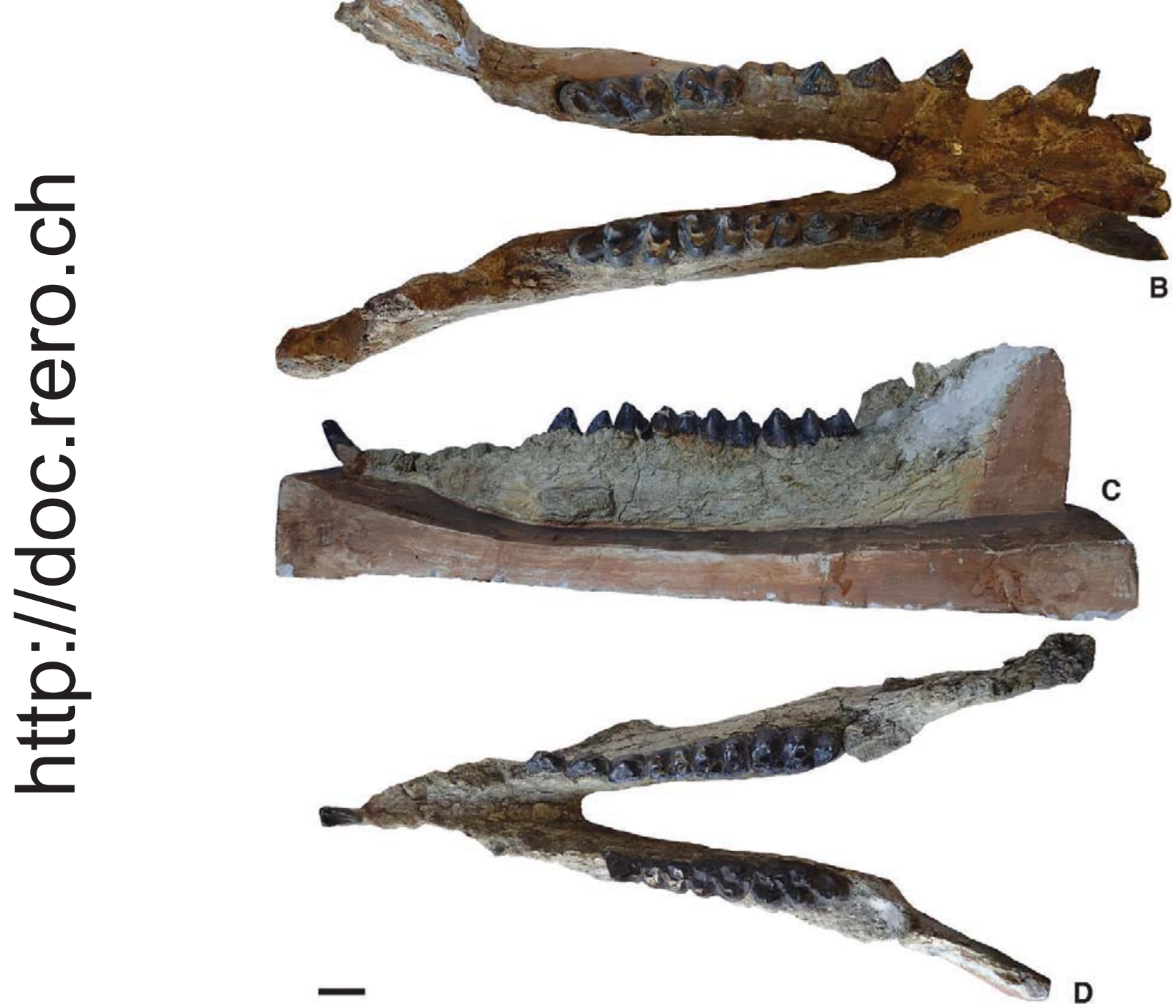

Figure 6. Mandibular remains of Paenanthracotherium bergeri gen. nov., sp. nov. from La Bénissons-Dieu, France. A, B, subcomplete mandible (FSL-213772, paratype) in lateral (A) and occlusal (B) views. C, D, subcomplete mandibule (FSL213774, paratype) in lateral (C) and occlusal (D) views. Scale bar: $5 \mathrm{~cm}$.

cristulid mesially directed in front of the hypoconulid (between the pre- and the posthypocristulid) on $\mathrm{m} 3$ $\left(46^{\circ}\right)$, the premetacristule divided into two mesial arms on the upper molars $\left(53^{1}\right)$, a fused symphysis in adult specimens $\left(74^{1}\right)$, the presence of a p2-p3 diastema $\left(87^{\circ}\right)$, and a postparafossa on P3 $\left(95^{\circ}\right)$. 


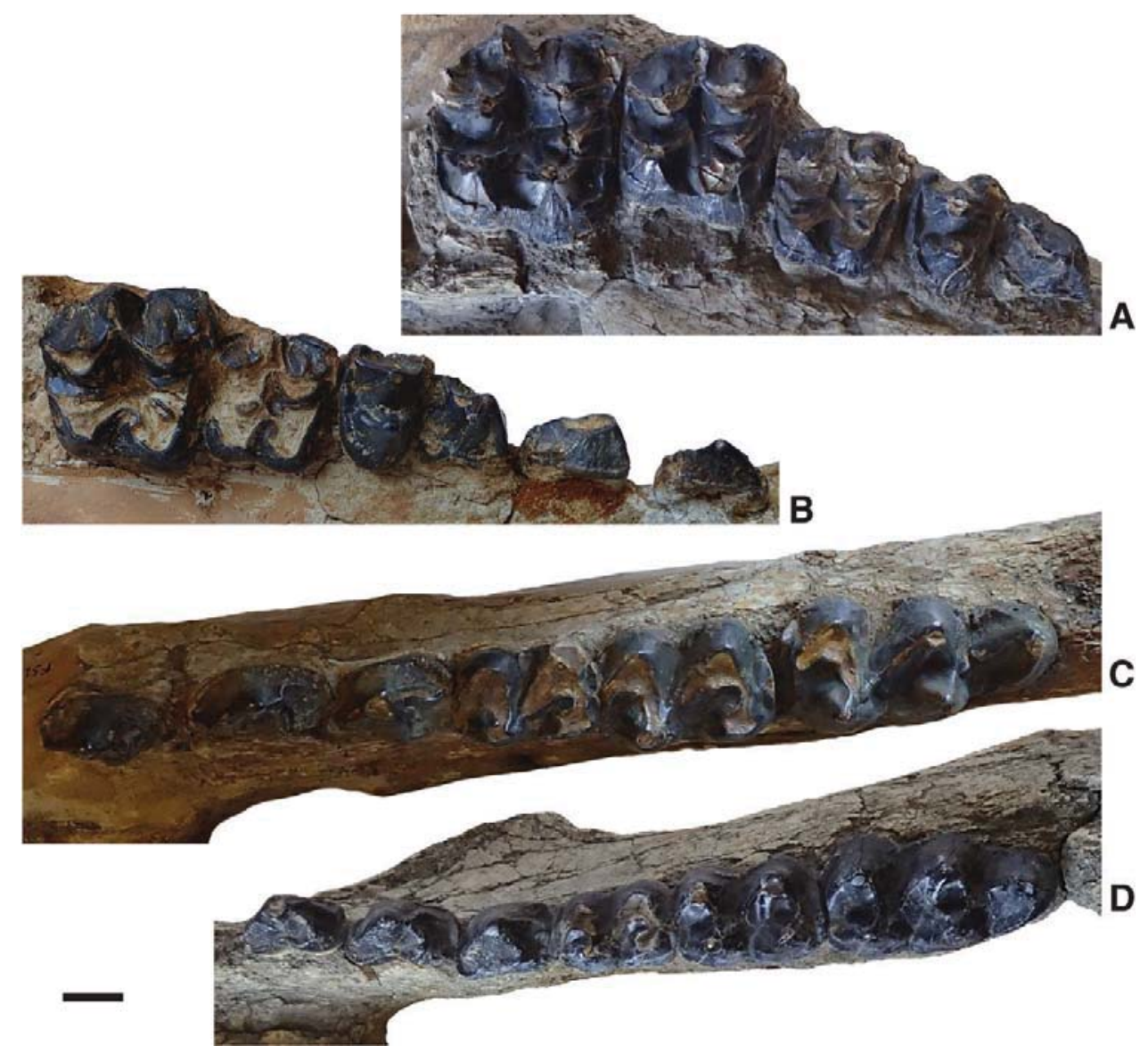

Figure 7. Dental views of Paenanthracotherium bergeri gen. nov., sp. nov. from La Bénissons-Dieu, France. A, right upper cheekteeth (FSL-213772, holotype). B, right upper cheekteeth (FSL-213773, paratype). C, right lower cheekteeth FSL-213774. D, right lower cheekteeth (FSL-213772, paratype). Scale bar: $2 \mathrm{~cm}$.

\section{Holotype}

Skull with left I2-P2, M3 and right I1-M2 (FSL213772) (Figs 5, 7).

\section{Paratypes}

Maxilla with left I1-I2, C-M3 and right I1-M3 (FSL213773), mandible with left i1, p4-m3 and right $\mathrm{p} 2$ m3 (FSL-213774), and mandible with left i1, i3-m3 and right i1, i3-c, p2-m3 (FSL-213772) (Figs 6, 7).

\section{Type locality and horizon}

La Bénisson-Dieu, France (late Early Oligocene, MP24).

\section{Etymology}

In memory of Jean-Pierre Berger, in recognition of his contribution to palaeontology and for having initiated the review of European anthracotheres.

\section{Distribution}

Oligocene of Europe: La Bénissons-Dieu (MP24), Digoin (MP24), Le Garouillas (MP25), Les Milles (MP26), Pech Desse (MP28), La Comberatière (MP29),
Moissac (Oligocene), Lamontgie (MP23-29?), France and Petrosani (Oligocene), Romania (e.g. De Blainville, 1848; Stehlin, 1910; Roman \& Boucher, 1936; Lavocat, 1951; Sudre, 1995; Hugueney, 1997; Scherler, 2011; Scherler et al., 2013; see Supporting Information, Appendix S5 for complete references).

\section{Remarks}

The fossils from La Bénissons-Dieu were previously assigned to A. bumbachense by Roman \& Boucher (1936), based on the reduced lateral metapods compared with the medial ones. It appeared that the specimens from Bumbach (Switzerland), assigned by Stehlin (1910) to the new species A. bumbachense, displayed a similar feature. However, when comparing the different metapods from La Bénissons-Dieu and Bumbach, there is a considerable variation in size and slenderness (Scherler, 2011). Additionally, owing to the scarcity and poor preservation of the material from Bumbach, the attribution of the skull, maxillae and mandibles from La Bénissons-Dieu to the same species is difficult and ambiguous. Moreover, the specimens from Bumbach 
cannot be assigned clearly to Anthracotherium for the above-mentioned reasons (Scherler, 2011). However, three incomplete mandibles from the French localities of Le Garouillas, Quercy (UM-GAR2313; Sudre, 1995), Moissac, Tarn et Garonne (MHNT.PAL.MAM.2002.3; Leymerie, 1851) and Lamontgie near Issoire, Puy de Dôme (figured in De Blainville, 1848: specimen Cr4223MNHN coll. Abbé Croizet in Lavocat, 1951; Hugueney, 1997) can be assigned, without doubt, to the same species based on the size, the more selenodont pattern than in A. magnum and the lack of an entoconulid on m3s. The taxon was named in an unpublished thesis (Scherler, 2011) and was cited later without formal description, diagnosis or figuration (Pickford, 2016). We thus consider Elliotherium murphyi to be a nomen nudum and propose Paenanthracotherium bergeri gen. nov., sp. nov. as the new name identifying the largest Paenanthracotherium species from Europe.

Figure 4 illustrates the size variations of the different specimens of Paenanthracotherium by plotting the $\mathrm{P} 4 / \mathrm{p} 4, \mathrm{M} 1 / \mathrm{m} 1, \mathrm{M} 2 / \mathrm{m} 2$ and $\mathrm{M} 3 / \mathrm{m} 3$, and Table 1 shows their mean values. The measurements of all studied specimens are given in the Supporting Information (Appendix S6). The two European species of Paenanthracotherium, $P$. bergeri and P. hippoideum, can be differentiated easily by their size, with the former being much larger than the latter. Moreover, these measurements help to confirm the attribution of the specimen from Pech Desse, France to P. bergeri.

\section{Description}

Upper dentition: The upper dentition formula is complete (3I, 1C, 4P, 3M). The upper incisors display a continuous and slightly developed lingual cingulum. Their lateral outline is triangular, with mesial and distal crests reaching the cingula. The incisor row is continuous, but there is a diastema between I3 and C. The upper canine is very large, with a high and sharp crown. Its transverse section is circular to ellipsoidal. P1 has a triangular occlusal outline and lacks any stylar development. The labial cingulum is weak and discontinuous, and the lingual one is slightly developed and continuous. The pre- and postparacristae are aligned and oblique in relationship to tooth row axis. The postparafossa is simple and weakly marked. P2 is similar to P1 but bears a slightly developed metastyle. The cingula are weak and continuous all around the tooth; the distal one is slightly more developed. It lacks an ectoparacrista, and the distolingual basin (endoparafossa) is simple and slightly developed. On P3, the para- and metastyles are developed. The cingula are continuous, but the mesial and labial ones are less developed compared with the distal and lingual ones. Moreover, the distolingual cingulum does not bear any protostyle, which is well developed in the Anthracotherium. The postparafossa is marked. The para- and metastyles on P4 are labially well developed, which differs in the species of Anthracotherium. The cingulum is present all around the tooth,

Table 1. Measurements of cheek teeth of the two European species of Paenanthracotherium gen. nov. (in millimetres), following our attributions

\begin{tabular}{|c|c|c|c|c|c|c|c|c|c|c|c|c|}
\hline \multirow[b]{2}{*}{ Tooth } & & \multicolumn{5}{|c|}{ Paenanthracotherium bergeri } & \multicolumn{5}{|c|}{ Paenanthracotherium hippoideum } & \multirow[b]{2}{*}{$P$-value } \\
\hline & & $N$ & Mean & Minimum & Maximum & $\mathrm{SD}$ & $N$ & Mean & Minimum & Maximum & $\mathrm{SD}$ & \\
\hline \multirow[t]{2}{*}{$\mathrm{P} 4$} & $\mathrm{~L}$ & 8 & 27.6 & 24.5 & 30.2 & 1.8 & 7 & 21.1 & 18.0 & 23.5 & 2.1 & $*$ \\
\hline & $\mathrm{W}$ & 8 & 35.0 & 33.5 & 36.5 & 1.1 & 7 & 28.7 & 21.5 & 31.0 & 3.5 & $*$ \\
\hline \multirow[t]{2}{*}{ M1 } & $\mathrm{L}$ & 4 & 34.9 & 29.1 & 37.5 & 3.9 & 5 & 31.3 & 29.0 & 34.5 & 2.2 & n.s. \\
\hline & $\mathrm{W}$ & 4 & 38.5 & 32.1 & 41.0 & 4.3 & 5 & 34.0 & 29.0 & 37.0 & 3.1 & n.s. \\
\hline \multirow[t]{2}{*}{ M2 } & $\mathrm{L}$ & 7 & 47.9 & 42.7 & 54.7 & 4.4 & 5 & 37.5 & 34.0 & 44.0 & 3.9 & $*$ \\
\hline & $\mathrm{W}$ & 7 & 51.2 & 42.6 & 57.3 & 5.5 & 4 & 42.4 & 40.0 & 45.5 & 2.4 & $*$ \\
\hline \multirow[t]{2}{*}{ M3 } & $\mathrm{L}$ & 5 & 52.1 & 48.6 & 56.5 & 3.4 & 5 & 44.4 & 38.0 & 50.5 & 5.4 & $*$ \\
\hline & $\mathrm{W}$ & 4 & 54.8 & 47.5 & 59.5 & 5.8 & 5 & 49.6 & 43.0 & 54.5 & 5.8 & n.s. \\
\hline \multirow[t]{2}{*}{$\mathrm{p} 4$} & $\mathrm{~L}$ & 11 & 35.0 & 31.5 & 42.0 & 3.5 & 4 & 27.9 & 23.5 & 31.5 & 4.0 & $*$ \\
\hline & $\mathrm{W}$ & 11 & 21.6 & 18.5 & 25.2 & 1.9 & 4 & 18.8 & 16.0 & 21.5 & 2.3 & $*$ \\
\hline \multirow[t]{2}{*}{$\mathrm{m} 1$} & $\mathrm{~L}$ & 9 & 36.1 & 32.9 & 41.0 & 2.6 & 6 & 30.3 & 24.5 & 33.0 & 3.2 & $*$ \\
\hline & $\mathrm{W}$ & 9 & 25.4 & 22.8 & 29.0 & 1.7 & 6 & 22.3 & 19.0 & 25.0 & 2.1 & $*$ \\
\hline \multirow[t]{2}{*}{$\mathrm{m} 2$} & $\mathrm{~L}$ & 14 & 45.2 & 40.1 & 49.5 & 2.8 & 6 & 37.2 & 31.5 & 41.5 & 3.6 & $*$ \\
\hline & $\mathrm{W}$ & 14 & 32.1 & 29.0 & 38.6 & 2.7 & 6 & 26.3 & 22.5 & 28.5 & 2.1 & $*$ \\
\hline \multirow[t]{2}{*}{$\mathrm{m} 3$} & $\mathrm{~L}$ & 11 & 70.6 & 60.4 & 80.5 & 5.9 & 7 & 58.2 & 50.0 & 63.5 & 4.8 & $*$ \\
\hline & $\mathrm{W}$ & 11 & 35.5 & 31.7 & 41.5 & 3.3 & 9 & 29.8 & 24.0 & 32.5 & 2.5 & $*$ \\
\hline
\end{tabular}

Student's unpaired $t$ test between mean value of the two species: $* P<0.05 ;$ n.s., $P>0.05$. Abbreviations: L, length; W, width. 
except labially, at the level of the paraconal rib. The endoprotocrista is slightly developed. The parafossae are marked (pre-) to slightly marked (ecto-, post- and endo-), whereas protofossae are weak (pre-, endo- and post-). The preprotocrista reaches the mesial cingulum, forming a slight mesiostyle distinct from the parastyle. A postectoprotocrista is present, lingually situated, and longer than the postprotocrista. Moreover, this crest reaches the distal cingulum instead of the postprotocrista and forms a bulbous distostyle. The postprotocrista is shorter and reaches the lingual wall of the paracone. It is more developed than in P. hippoideum but less than in all Anthracotherium species, where this crest reaches the distostyle instead of the postectoprotocrista.

Upper molars display the general pattern of Anthracotheriinae. The parastyle is strong, oblique and lingually linked to the preparacrista. The mesostyle is strong, vertical and slightly broad. The metastyle, albeit small compared with other species of Paenanthracotherium, is more developed and oblique on M3 than on the other molars. The protostyle (which is mesial to the protocone and lingual to the mesiostyle) is visible (but not as developed as in Anthracotherium) and not linked to the preprotocrista. The distostyle is weak and reached by a postmetacristule but does not bear any accessory labial cristae or cusps as observed in Anthracotherium (Fig. 3). The cingula are well developed and continuous, except lingually at the level of the transverse valley and around the metaconule. The ribs of the labial cusps are salient, forming ectocristae that are labially directed. The postprotocrista is long and medially directed. The postectoprotocrista is also medially directed but is shorter and less salient than the postprotocrista. The premetacristule is divided into two mesial arms, one joining the metacone and one being directed towards the protocone, most of the time reaching the postprotofossa or the postectoprotocrista. There is a slightly developed endometacristule that is labially directed. The ectometacristule is mesiolingually oriented and reaches the lingual cingulum, forming an entostyle at level of the transverse valley. The ecto- and postparafossae and the postmetafossa are marked. The postparacristule does not invade the transverse valley.

Lower dentition: The lower dentition formula is complete (3i, 1c, 4p, 3m). The lower incisors are linguolabially compressed and display a rectangular section. The distal cingulid is developed. The incisors were poorly preserved on the paratypes, excluding i1, which displays a high crown. The lower canine is very large, with an ellipsoidal section. It shows a high and curved crown that tappers apically as a fang. The $\mathrm{p} 1$ is uniradiculate and contacts the canine. The $\mathrm{p} 2$ is separated from $\mathrm{p} 1$ by a diastema. The distal cingulid is more developed than the mesial and lingual ones, and the labial cingulid is absent. The preprotocristid lacks a mesial accessory cristid. The post- and endoprotofossids are well marked on each side of the postprotocristid. The latter has a distolabial orientation that differs from the distal orientation in Anthracotherium. An endoprotocristid reaches the cingulid distolingually and forms a small entostylid. The p3 resembles $\mathrm{p} 2$, being slightly larger and separated from it by a small diastema. This tooth differs from that of Anthracotherium by the distolabial orientation of its postprotocristid and by the presence of an entostylid and of accessory crests on the preprotocristid. On p4, the mesial and distal cingulids are more developed than the lingual and labial cingulids, which are absent in most specimens. The distolingual cingulid is marked and forms a continuous wall that reaches the distostylid. There is a developed accessory crest that is distally directed, initiating from the preprotocristid and joining the entostylid. The postprotofossid is less developed than the endoprotofossid.

On all observed lower molars, a postectoprotocristid is slightly developed. Between the post- and the postectometacristids, there is a long and developed accessory cristid that is medially directed and that joins the prehypocristid. The postectoentocristid is distally directed and well developed. Fossids are also important to describe the patterns of the lower molars, notably the presence of an ectometafossid, which character is not observed in other species of the genus Paenanthracotherium. The $\mathrm{m} 1$ and $\mathrm{m} 2$ are subrectangular. The distostylid is slightly more developed than the preentostylid. The mesial cingulid is thinner than the distal one; the labial cingulid is weak and short and present only at the level of the transverse valley, where it forms an ectocristylid. There is a strong premetacristid that does not contact the preprotocristid. The prehypocristid is slightly inflated mesially. There is an endohypocristid but no hypolophid, because it does not contact the preentocristid. The posthypocristid reaches the postentocristid. The $\mathrm{m} 3$ resembles $\mathrm{m} 1$ and $\mathrm{m} 2$, but with a distal hypoconulid. It is important to note the absence of an entoconulid, because its presence is characteristic of Anthracotherium within Anthracotheriinae. The preentostylid is more salient than in other molars. There are no distal or lingual cingulids. The pre- and the posthypocristulids form a loop with a unique accessory cristulid that is mesially directed in front of the hypoconulid. The ectohypocristulid is barely developed (not reaching the hypoconulid tip) and is labially directed, joining the labial cingulid.

Skull and mandibles: Roman \& Boucher (1936: 26, 29) described precisely the skull and mandible nominated in this study as the holotype (FSL-213772) and one of the paratypes (same number) of $P$. bergeri. 
It is worth highlighting here that the skull is well preserved and shows only a lateral compression. Its general shape is elongated, and the incisors are slightly proclive. The mandible is well preserved but lacks its ventral part. It shows particularly proclive incisors and a fused symphysis. On the second mandible (paratype FSL-213774), a bilateral protuberance at the level of the p3-p4 can be observed, a character that cannot be objectivized on the other one (FSL-213772).

\section{Genus ANTHRACOTHERIUM CUVIER, 1822}

The attribution of anciently described material of Anthracotherium tothenewgenusPaenanthracotherium led us to emend Anthracotherium as follows.

\section{Emended diagnosis}

Medium to large Anthracotheriinae s.l., with bunodont cheek teeth. Lower molars with fully developed postectoprotocristid $\left(17^{1}\right)$, postprotofossid $\left(18^{1}\right)$ and posthypofossid $\left(35^{1}\right)$, a prehypocristid divided into two mesial arms $\left(29^{\circ}\right)$, m3 with an entoconulid on its talonid $\left(42^{1}\right)$, the lack of an accessory cristulid issued from the hypoconulid and mesially directed between the pre- and the posthypocristulid on m3 $\left(46^{1}\right)$. Upper molars with parastyle smaller or equal to mesostyle $\left(68^{1}\right)$ and with the presence of an endometacrista $\left(60^{1}\right)$.

\section{Differential diagnosis}

Anthracotherium differs from all other Anthracotheriinae by the presence of an entoconulid on $\mathrm{m} 3\left(42^{1}\right)$. It differs from Heptacodon, Paenanthracotherium gen. nov. and Prominatherium by a smaller or equal parastyle compared with the mesostyle $\left(68^{1}\right)$. It further differs from Heptacodon and Paenanthracotherium gen. nov. by a fully developed postectoprotocristid on the lower molars (171), the presence of a postprotofossid (18 1 ), a prehypocristid dividing into two mesial arms on the lower molars $\left(29^{\circ}\right)$ and the presence of a posthypofossid on the lower molars $\left(35^{1}\right)$. Anthracotherium differs from Paenanthracotherium gen. nov. in having no entostylid on p3 $\left(6^{\circ}\right)$, the main arm of the prehypocristid connecting the trigonid distal wall $\left(32^{\circ}\right)$, a mesiodistal development of the ribs of labial cusps on the upper molars of almost half of the molar length $\left(48^{\circ}\right)$, an endometacristule or secondary cristids labial to the metaconule (56 1 ), and a well-developed cingular style on the distolingual cingulum of P3 (91'1). It differs from Heptacodon by a strong premetacristid on lower molars $\left(15^{\circ}\right)$, the presence of an ectoentocristid $\left(27^{\circ}\right)$, a premetacristule divided into two mesial arms $\left(53^{1}\right)$, a postparacristule extending towards the transverse valley $\left(59^{1}\right)$, a diastema between $\mathrm{p} 1$ and $\mathrm{p} 2\left(86^{1}\right)$, a postparafossa on P3 $\left(95^{\circ}\right)$ and no postprotofossa on P4 $\left(106^{\circ}\right)$. Anthracotherium differs from Heptacodon and Anthracokeryx in having a distolingual cingulid on p4 forming a continuous wall $\left(7^{\circ}\right)$, an inflated prehypocristid in the transverse valley of the lower molars $\left(30^{1}\right)$, an incomplete ectohypocristulid on m3 (391; complete in Anthracokeryx and absent in Heptacodon), the lack of an accessory cristulid mesial to the hypoconulid on $\mathrm{m} 3\left(46^{1}\right)$ and the lack of cristids on lower canine $\left(80^{\circ}\right)$. It differs from Anthracokeryx and Prominatherium by a distostyle that is at the level of the metacone and not the metaconule on the upper molars $\left(57^{1}\right)$, and further differs from Anthracokeryx by a postentocristid on $\mathrm{m} 1$ and $\mathrm{m} 2\left(28^{1}\right)$, the presence of a postectoprotocrista $\left(49^{1}\right)$, a mesiolingual style (= protostyle) on the mesial cingulum of the upper molars $\left(66^{1}\right)$, a fully developped metastyle $\left(70^{1}\right)$, a postprotocrista on $\mathrm{P} 4$ that joins the distostyle (991) and a concave to straight mesial margin on $\mathrm{P} 4\left(102^{\circ}\right)$.

\section{Type species}

Anthracotherium magnum Cuvier, 1822 from Cadibona (Italy), early Late Oligocene (MP25).

\section{Other included species}

Anthracotherium monsvialense De Zigno, 1888; A. bugtiense Pilgrim, 1907; A. kwablianicum (Gabounia, 1964); A. chaimanei Ducrocq, 1999.

\section{Doubtful species}

Anthracotherium alsaticum Cuvier, 1822; A. valdense Kowalevsky, 1873; A. seckbachense Kinkelin, 1884; A. illyricum Teller, 1886; A. bumbachense Stehlin, 1910; A. bimonsvialense-magnum Golpe-Posse, 1972.

\section{Distribution}

In Asia, late Eocene of Thailand and Oligocene of Pakistan and in Europe, Oligocene (MP21-29) of France, Georgia, Germany, Italy, Spain and Switzerland (e.g. Kowalevsky, 1873; Teller, 1886; Stehlin, 1910; Gabounia, 1964; Ducrocq, 1999; Scherler, 2011; Scherler et al., 2013; see Supporting Information, Appendix S5 for a more exhaustive list of localities and references).

\section{Remarks on the collection from Mouillac}

The specimens from Mouillac (France) differ only very slightly from the type species, $A$. magnum from Cadibona, in having a slightly larger size (Fig. 8; Supporting Information, Appendix S6), a smaller hypoconid on $\mathrm{p} 4$, a smaller endohypocristid on the lower molars, and a posthypocristid reaching the postentocristid on $\mathrm{m} 1$ and $\mathrm{m} 2$ instead of directly joining the distostylid. As inferred from the present phylogeny and taking into account the weak variation, we conclude that the specimens from Mouillac should be assigned to $A$. magnum. 

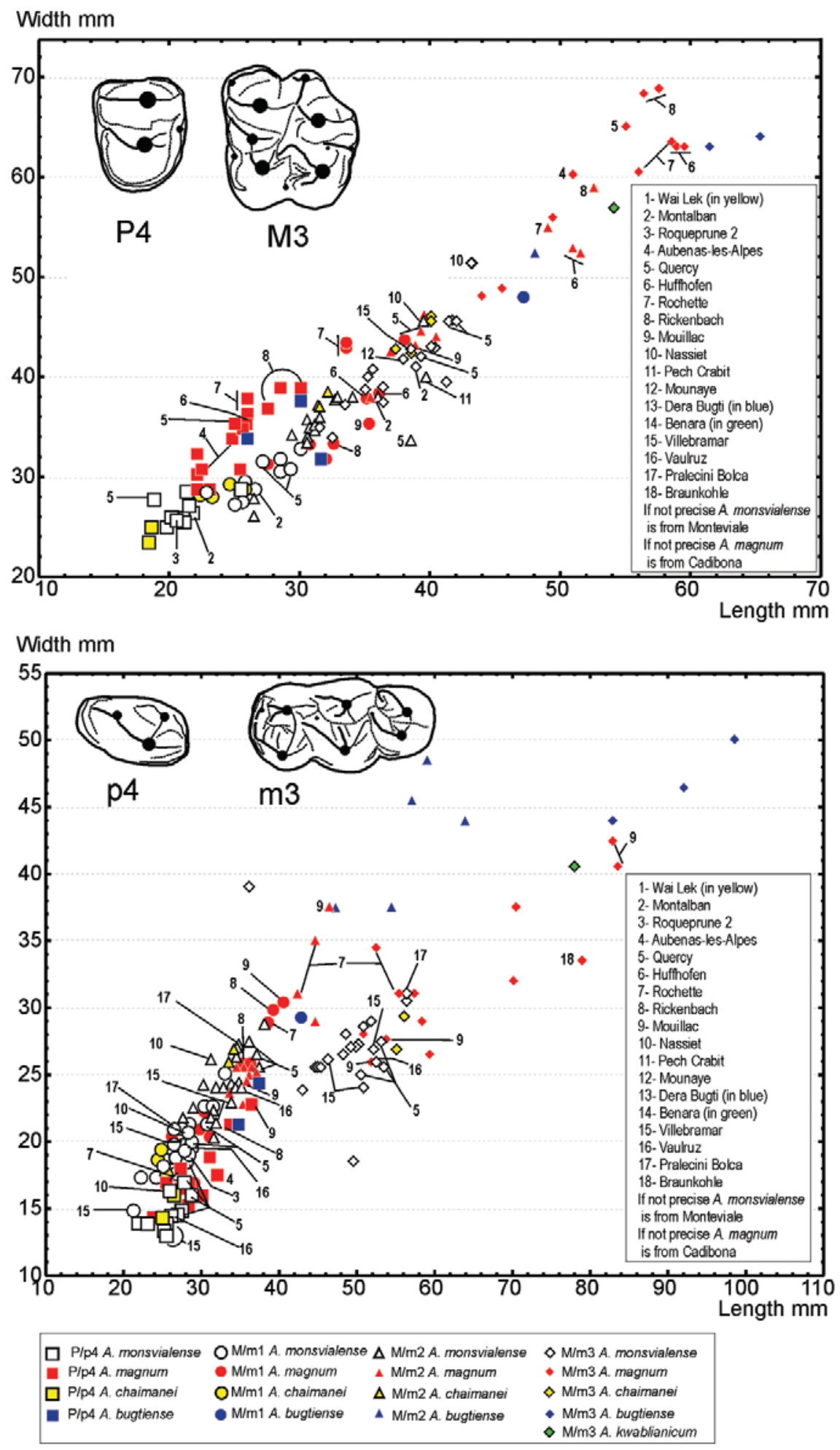

Figure 8. Length and width of upper and lower molars (M/m1, M/m2 and M/m3) and premolars (P/p4) of the five species of Anthracotherium, namely Anthracotherium magnum, Anthracotherium monsvialense, Anthracotherium bugtiense, Anthracotherium chaimanei and Anthracotherium kwablianicum (in millimetres). Numbers indicate the localities from which the different specimens come. 
Remarks on the doubtful species

Anthracotherium alsaticum was described based on the fragmentary mandible of a juvenile individual. Although its assignment to Anthracotherium is clear, its attribution to a species different from A. magnum remains doubtful, because this species displays a large intraspecific variability concerning the size and tooth morphology (e.g. Squinabol, 1890).

Anthracotherium valdense was subject to many synonymies with $A$. magnum since its first description (e.g. De La Harpe, 1854; Rütimeyer, 1857; Stehlin, 1910; Scherler, 2011). It differs from the type species only by its well-developed distostylid, or distal cingulid, on $\mathrm{m} 3$. It ranges within the size variability of $A$. magnum (Scherler, 2011), and its assignment to a proper species is, indeed, questionable.

Regarding the species A.? illyricum and A.? bumbachense, their attribution to Anthracotherium cannot be confirmed owing to the scarcity of the discovered fossils and/or their poor preservation.

Regarding A. bimonsvialense-magnum, represented by only a fragmentary right maxilla with P3-M3 (holotype:IPS1738, collection of the Museum of Sabadell, Spain), the genus attribution is certain, but the specific assignment remains doubtful. Some characters confirm its attribution to Anthracotherium: the prominent distolingual style and the well-developed ecto- and postprotofossae on P3, the presence of enamel knobs on the labial side of the metaconule on upper molars, and the general quadratic shape of upper molars, with a parastyle slightly smaller than the mesostyle. However, the size differences proposed by Golpe-Posse (1972) are concordant with the important size variability within the genus and notably within A. monsvialense (Ghezzo \& Giusberti, 2016; Fig. 8; Supporting Information, Appendix S6). Therefore, we suggest that it should be synonymized with $A$. monsvialense.

Remarks on the size variability of Anthracotherium Figure 8 shows the measurements of upper and lower molars and p4/P4 of each species of Anthracotherium mentioned here. The measurements of each studied species are in the Supporting Information (Appendix S6). Size may help to discriminate the species of Paenanthracotherium but cannot be used for Anthracotherium. Hence, the differentiation of a small specimen of $A$. magnum from a large $A$. monsvialense is not easy. Furthermore, these measurements confirm earlier assumptions (e.g. Squinabol, 1890) concerning the large variability of $A$. magnum.

\section{PALAEOBIOGEOGRAPHICAL IMPLICATIONS}

Figure 9 illustrates the distribution of anthracotheriines in Eurasia and North America from their origin in the Eocene until their extinction in the end of the
Oligocene. Our phylogenetic study corroborates that anthracotheres originated in Asia and began their early diversification from the Bartonian. The Pondaung formation in Myanmar revealed a high diversity and abundance of Hippopotamoidea (see Tsubamoto et al., 2002; Soe, 2008) and could be dated to the middle Bartonian (40.2 $\pm 0.5 \mathrm{Mya})$ after $\mathrm{U}-\mathrm{Pb}$ age analyses on zircons by Zaw et al. (2014). According to our phylogenetic results, representatives of the three main clades are present in this fossil formation (stem Hippopotamoidea, Microbunodontinae + Bothriodontinae and Anthracotheriinae with A. pangan, Anthracokeryx tenuis and Anthracokeryx birmanicus, respectively). From the Texan deposits, supposed to be close in age (early Duchesnean = middle Bartonian; Vandenberghe et al., 2012), Holroyd (2002) described a representative of Anthracotheriinae, Heptacodon yeguaensis, that demonstrates the first dispersal event of the family. The exact origin of anthracotheres might thus have taken place earlier in the beginning of the Bartonian or in the late Lutetian of Southeast Asia.

The diversity of anthracotheres is related to the dispersal events recorded in each subfamily (see Lihoreau et al., 2004 for Microbunodontinae; Lihoreau et al., 2015 for Bothriodontinae). We observed the same phenomena within Anthracotheriinae, but our revised phylogeny and systematics of the subfamily suggest a more complex sequence of events than previously stated. Given that Prominatherium is known by few remains and its position in our phylogeny can be ambiguously related to Heptacodon, we suggest that it represents the first expansion from Asia to Europe during the Priabonian. This is confirmed by corresponding deposits from Croatia (Hellmund \& Heissig, 1994), Romania (Patrulius, 1954) and Italy (Grandi \& Bona, 2017) (Fig. 9). This first arrival in Southeastern Europe earlier than the Grande Coupure Event (Stehlin, 1909) suggests a maritime path, because no terrestrial connection existed. Accordingly, it is interesting to note that all this material was found in coastal marine deposits, suggesting that this species was dispersing via an archipelago, as Southern Europe was at this time (Grandi \& Bona, 2017). This is in agreement with the alleged aquatic habits of some representatives of Hippopotamoidea (e.g. Lihoreau et al., 2015), but anthracotheres had probably not developed such habits enough to allow them to cross the Perialpine and Paratethys seas and settle in Western Europe. According to our results, Prominatherium is not related to subsequent European Anthracotheriinae, suggesting the extinction of this genus before the Oligocene. Hence, two new dispersal events can be recorded, with the arrival of Anthracotherium during the Grande Coupure Event (MP21) and the genus Paenanthracotherium with a possible slight delay (MP22 with Céreste and MP23 with Briatexte; 

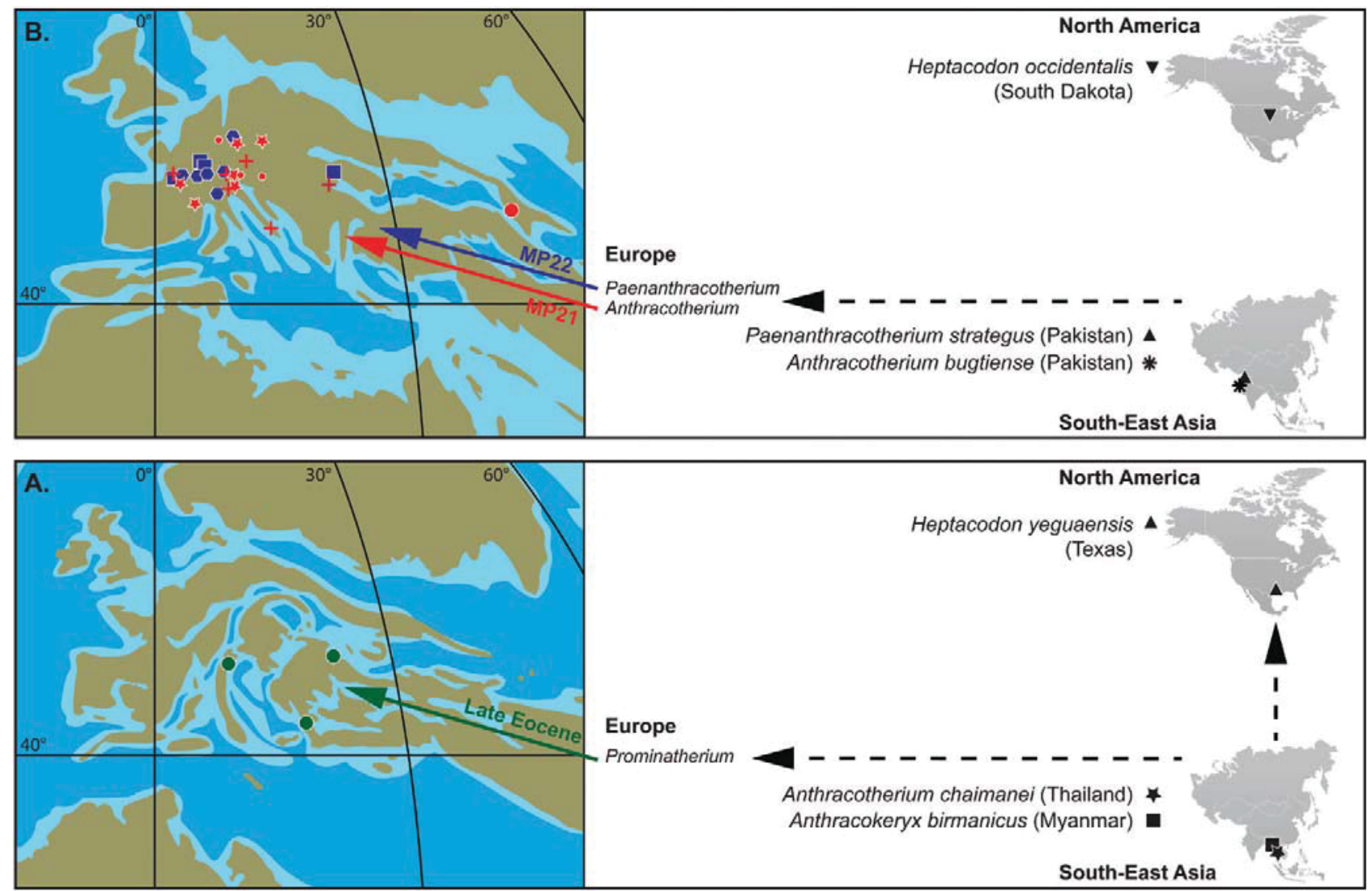

\begin{tabular}{|l|ll|}
\hline B. & & * Anthracotherium bugtiense \\
& & + Anthracotherium magnum \\
Oligocene & & - Anthracotherium kwablianicum \\
& & $*$ Anthracotherium monsvialense \\
& v Heptacodon occidentalis & Anthracotherium ?alsaticum, ?illyricum, ?bumbachense
\end{tabular}

Figure 9. Distribution of anthracotheriines in Eurasia and North America. Reconstructions of palaeogeographical maps of the Eocene (A) and the Oligocene (B) are modified from Ron Blakey (deeptimemaps.com). See the Supporting Information (Appendix S5) for localities and references of Paenanthracotherium gen. nov. and Anthracotherium. See Holroyd (2002), Lihoreau \& Ducrocq (2007) and Grandi \& Bona (2017) for localities and occurrences of Heptacodon, Anthracokeryx and Prominatherium.

Supporting Information, Appendix S5). Neither genus crossed the Oligocene-Miocene boundary, and they even seemed to disappear shortly before (at least in Europe, last occurrences of $P$. bergeri and $A$. magnum are dated to the European Mammal Level MP29; Scherler et al., 2013; Supporting Information, Appendix S5). Similar cases can be observed in other large mammal taxa. For instance, three genera (Bakalovia, Amynodontopsis and Bachitherium) seem to show an early dispersal of bothriodontines, rhinocerotoids and ruminants, respectively, towards the South Alpine and Carpathian Europe, whereas new representatives of the same taxa, such as Bothriodon, Elomeryx, Epiaceratherium, Ronzotherium and Bachitherium, hint at the new arrivals in Western Europe after the Grande Coupure Event (Lihoreau \& Ducrocq, 2007; Boehme et al., 2013; Mennecart et al., 2018; Tissier et al., 2018). It is worth noting that Elomeryx also occurs in the Late Eocene of Western Europe, with E. crispus from La Débruge (MP18, France) (BiochroM'97, 1997). This occurrence is still incompletely understood, because Elomeryx is considered paraphyletic and might be the stem group of several lineages of anthracotheres on different landmasses (Lihoreau \& Ducrocq, 2007). For a better 
understanding of its evolutionary history, a detailed review of this genus is needed, as stated by the same authors.

Finally, the geographical repartition of the large selenodont Paenanthracotherium and the robust bunodont Anthracotherium seems congruent with niche partitioning. Indeed, even if the presence of both genera might not be evident in all localities (evidence in the Bugti Hills, Pakistan and, possibly, in Le Garouillas, France), they are both present in the same regions (France, Germany, Switzerland and Pakistan). This distribution may also represent a difference in habitat preference, potentially linked to aquatic environments (Tütken \& Absolon, 2015) or food preferences, i.e. plant consumption (Sieber, 1936).

\section{CONCLUSION}

To review anthracotheriine systematics and understand the early phylogenetic divergence within the superfamily, it is crucial to describe the diversity of hippopotamoids through time and to describe the main dispersal events of large mammals during the Late Palaeogene. The phylogenetical hypothesis presented here differs from previous scenarios by proposing at least three dispersions of anthracotheriines from Asia towards North America and Europe. This new scenario is indicated by the presence of Anthracotherium in the late Eocene in Thailand (Ducrocq, 1999). A similar distribution is observed for the genus Epiaceratherium (Rhinocerotidae), with the record of Epiaceratherium naduongense Boehme et al., 2013 from the Late Eocene in Northern Vietnam and the first European occurrence of this genus (Epiaceratherium bolcense Abel, 1910) in the early Oligocene in Northern Italy (Becker, 2009; Boehme et al., 2013). However, early Asian species of Paenanthracotherium need to be recovered to gain a better understanding of the palaeogeographical distribution of Anthracotheriinae. We suggest a systematic revision of Chinese anthracotheriines and profound analysis of the origin of Prominatherium and Heptacodon. Consequently, this paper is the first step in a complete review of the subfamily. Additionally, this study reveals the presence of two large anthracotheriines during the Oligocene in Europe and Pakistan; hence, it is crucial to study the palaeoecology of both taxa to understand the niche partitioning that occurred within the family and to compare it with that of the other contemporaneous large mammals (e.g. Rhinocerotidae and Entelodontidae).

\section{ACKNOWLEDGEMENTS}

We are grateful to the curators for giving us access to the collections of the MHNM (S. Jouve), NMB (L. Costeur), NMBE (U. Menkveld-Gfeller), FSL
(A. Prieur and E. Robert), UM (B. Marandat), MHNT (Y. Laurent) and NHM (P. Brewer). We would like to thank P.-O. Antoine, M. Orliac and L. Marivaux for fruitful discussions and for providing us with pictures of A. kwablianicum. Editor Dr Louise Allcock and two anonymous reviewers provided very helpful comments on the manuscript. L.S. was funded by an Early Postdoc Mobility grant from the Swiss National Science Foundation (PBFRP2-145876) and obtained support from SPLASH, a research programme (ANR15-CE32-0010-01) of the Agence Nationale pour la Recherche. D.B. was financially supported by the Swiss National Science Foundation (project 200021_162359).

\section{REFERENCES}

Alloing-Séguier L, Lihoreau F, Boisserie JR, Charruault AL, Orliac M, Tabuce R. 2014. Enamel microstructure evolution in anthracotheres (Mammalia, Cetartiodactyla) and new insights on hippopotamoid phylogeny. Zoological Journal of the Linnean Society 171: 668-695.

Becker D. 2009. Earliest record of rhinocerotoids (Mammalia: Perissodactyla) from Switzerland: systematics and biostratigraphy. Swiss Journal of Geosciences 102: 489-504.

Becker D, Lapaire F, Picot L, Engesser B, Berger JP. 2004. Biostratigraphie et paléoécologie du gisement à vertébrés de La Beuchille (Oligocène, Jura, Suisse). Revue de Paléobiologie 9: 179-191.

BiochroM'97. 1997. Tableaux de corrélations et synthèses. In: Aguilar JP, Legendre S, Michaux J, eds. Actes du congrès BiochroM'97. Montepellier: Ecole pratique des Hautes Etudes, Institut Montpellier, 769-805.

Boehme M, Aiglstorfer M, Antoine PO, Appel E, Havlik P, Métais G, The Phuc L, Schneider S, Setzer F, Tappert R, Ngoc Tran D, Uhl D, Prieto J. 2013. Na Duong (northern Vietnam): an exceptional window into Eocene ecosystems from Southeast Asia. Zitteliana 53: 121-167.

Boisserie JR, Fisher RE, Lihoreau F, Weston EM. 2011. Evolving between land and water: key questions on the emergence and history of the Hippopotamidae (Hippopotamoidea, Cetancodonta, Cetartiodactyla). Biological Reviews 86: 601-625.

Boisserie JR, Lihoreau F, Brunet M. 2005. The position of Hippopotamidae within Cetartiodactyla. Proceedings of the National Academy of Sciences of the United States of America 102: 1537-1541.

Boisserie JR, Lihoreau F, Orliac M, Fisher RE, Weston EM, Ducrocq S. 2010. Morphology and phylogenetic relationships of the earliest known hippopotamids (Cetartiodactyla, Hippopotamidae, Kenyapotaminae). Zoological Journal of the Linnean Society 158: 325-366.

Brunet M. 1970. Villebramar (Lot-et-Garonne): très important gisement de vertébrés stampien inférieur du Bassin d'Aquitaine. Comptes Rendus de l'Académie des Sciences de Paris 270: 2535-2538.

Brunet M, Vianey-Liaud M. 1987. Mammalian reference levels MP 21-30. Münchner Geowissenschaftliche Abhandlungen (A) 10: 30-31. 
Chaimanee Y, Chavasseau O, Lazzari V, Euriat A, Jaeger JJ. 2013. A new Late Eocene primate from the Krabi Basin (Thailand) and the diversity of Palaeogene anthropoids in southeast Asia. Proceedings of the Royal Society B: Biological Sciences 280: 2013-2268.

Cuvier G. 1822. Recherches sur les ossements fossiles, où l'on rétablit les caractères de plusieurs animaux, dont les révolutions du globe ont détruit les espèces, Tome 5. Paris: E. d'Ocagne.

De Blainville HMD. 1848. Ostéographie ou, description iconographique comparée du squelette et du système dentaire des cinq classes d'animaux vertebres recents et fossiles pour servir de base à la zoologie et à la geologie. Paris: J.B. Baillière et fils.

De La Harpe P. 1854. Ossements appartenant à l'Anthracotherium magnum recueillis dans les lignites des environs de Lausanne. Bulletin de la Société Vaudoise des Sciences Naturelles 4: 1-14.

Depéret C. 1913. The Oligocene of the Roanne Basin and its vertebrate fauna. American Journal of Science 35: 350-352.

Ducrocq S. 1997. The anthracotheriid genus Bothriogenys (Mammalia, Artiodactyla) in Africa and Asia during the Paleogene: phylogenetical and paleobiogeographical relationships. Stuttgarter Beitrage zur Naturkunde, Serie B 250: 1-44.

Ducrocq S. 1999. The late Eocene Anthracotheriidae (Mammalia, Artiodactyla) from Thailand. Palaeontographica 252: 93-140.

Ducrocq S, Soe AN, Aung AK, Benammi M, Bo B, Chaimanee Y, Tun T, Thein T, Jaeger JJ. 2000. A new anthracotheriid artiodactyl from Myanmar, and the relative ages of the Eocene anthropoid primate-bearing localities of Thailand (Krabi) and Myanmar (Pondaung). Journal of Vertebrate Paleontology 20: 755-760.

Erfurt J, Métais G. 2007. Endemic European Paleogene artiodactyls: Cebochoeridae, Choeropotamidae, Mixtotheriidae, Cainotheriidae, Anoplotheriidae, Xiphodontidae, and Amphimerycidae. In: Prothero DR, Foss SE, eds. The evolution of artiodactyls. Baltimore: The John Hopkins University Press, 59-84.

Filhol H. 1877. Recherches sur les phosphorites du Quercy: étude des fossiles qu'on y rencontre et spécialement des mammifères, Vol. 2. Paris: G. Masson.

Fischer-Ooster C. 1861. Aufzählung der bis dahin in der Süsswassermolasse vom Bumbachgraben bei Schangnau entdecken fossilen Thieren. Mitteilungen der Naturforschenden Gesellschaft Bern 1861: 217-222.

Forster-Cooper C. 1913. New anthracotheres and allied forms from Baluchistan.-Preliminary notice. Annual Magazine of Natural History 12: 514-522.

Gabounia LK. 1964. The Oligocene mammalian fauna of Benara. Tbilissii: Academy of Sciences of the USSR, 1-267.

Gaudry A. 1873. Sur l'Anthracotherium découvert à SaintMenoux (Allier). Bulletin de la Société Géologique de France 2: $36-40$.

Gentry AW, Hooker JJ. 1988. The phylogeny of the Artiodactyla. In: Benton MJ, ed. The phylogeny and classification of the tetrapods, Volume 2: Mammals, vol 35B Systematics Association Special Volume. Oxford: Clarendon Press, 235-272.
Gervais P. 1852. Zoologie et paléontologie française, Tome 1. Paris: Arthus Bertrand.

Gill T. 1872. Arrangement of the families of mammals and synoptical tables of characters of the subdivisions of mammals. Smithsonian Miscelaneous Collections 203: 1-98.

GhezzoE, Giusberti L.2016. New insights on Anthracotherium monsvialense De Zigno, 1888 (Mammalia, Cetartiodactyla) from the lower Oligocene of Monteviale (Vicenza, northeastern Italy). Rivista Italiana di Paleontologia e Stratigrafia 122: 119-140.

Golpe-Posse JM. 1972. Suiformes del Terciario Español y sus yacimientos. PhD Thesis. Publicaciones del Instituto Provincial de Paleontologia de Sabadell, Paleontologia y Evolucion 2: 1-197.

Grandi F, Bona F. 2017. Prominatherium dalmatinum from the late Eocene of Grancona (Vicenza, NE Italy). The oldest terrestrial mammal of the Italian peninsula. Comptes Rendus Palevol 16: 738-745.

Hellmund M, Heissig K. 1994. Neuere Funde von Prominatherium dalmatinum (H. v. Meyer 1854) (Artiodactyla, Mammalia) aus dem Eozän von Dalmatien. Mitteilungen der Bayerischen Staatssammlung für Paläontologie und historische Geologie 34: 273-281.

Holroyd PA. 2002. New record of Anthracotheriidae (Artiodactyla: Mammalia) from the middle Eocene Yegua Formation (Claiborne Group), Houston County, Texas. Texas Journal of Science 54: 301-308.

Hooker JJ, Thomas KM. 2001. A new species of Amphirhagatherium (Choeropotamidae, Artiodactyla, Mammalia) from the late Eocene Headon Hill Formation of southern England and phylogeny of endemic European 'anthracotherioids'. Palaeontology 44: 827-853.

Hugueney M. 1997. Biochronologie mammalienne dans le Paléogène et le Miocène inférieur du Centre de la France: synthèse réactualisée. In: Aguilar JP, Legendre S, Michaux J, eds. Actes du congrès BiochroM'97. Montepellier: Ecole pratique des Hautes Etudes, Institut Montpellier, 417-430.

Kinkelin F. 1884. Ueber Fossilien aus Braunkohlen der Umgebung von Frankfurt am Main. Berichte der Senckenbergische Naturforschende Gesellschaft in Frankfurt am Main 1884: 165-182.

Kotsakis T. 1984. Problemi paleobiogeografici dei mammiferi fossili italiani: le faune oligoceniche. Geologica Romana 23: 141-156.

Kowalevsky W. 1873. Monographie der Gattung Anthracotherium Cuvier und Versuch einer natürlichen Classification der fossilen Hufthiere. Palaeontographica 3: $1-347$.

Kron DG, Manning E. 1998. Anthracotheriidae. In: Janis CM, Scott KM, Jacobs LL, eds. Evolution of Tertiary mammals of North America. Cambridge: Cambridge University Press, 381-388.

Lavocat R. 1951. Révision de la faune des mammifères oligocènes d'Auvergne et du Velay. Paris: Sciences et Avenir.

Leymerie A. 1851. Note sur un Anthracotherium magnum découvert à Moyssac. Mémoires de l'Académie des Sciences., Paris, 4e série 1: 388-394. 
Lihoreau F, Alloing-Séguier L, Antoine PO, Boisserie JR, Marivaux L, Métais G, Welcomme JL. 2017. Enamel microstructure defines a major Paleogene hippopotamoid clade: the Merycopotamini (Cetartiodactyla, Hippopotamoidea). Historical Biology 29: 947-957.

Lihoreau F, Blondel C, Barry J, Brunet M. 2004. A new species of the genus Microbunodon (Anthracotheriidae, Artiodactyla) from the Miocene of Pakistan: genus revision, phylogenetic relationships and palaeobiogeography. Zoologica Scripta 33: 97-115.

Lihoreau F, Boisserie JR, Manthi FK, Ducrocq S. 2015. Hippos stem from the longest sequence of terrestrial cetartiodactyl evolution in Africa. Nature Communications 6: 6264.

Lihoreau F, Ducrocq S. 2007. Family Anthracotheriidae. In: Prothero DR, Foss SE, eds. The evolution of artiodactyls. Baltimore: The John Hopkins University Press, 89-105.

Macdonald JR. 1956. The North American anthracotheres. Journal of Paleontology 30: 615-645.

Mennecart B, Geraads D, Spassov N, Zagorchev I. 2018. Discovery of the oldest European ruminant in the latest Eocene of Bulgaria: did tectonics influence the diachronic development of the Grande Coupure? Palaeogeography, Palaeoclimatology, Palaeoecology 498: 1-8.

Orliac M, Boisserie JR, MacLatchy L, Lihoreau F. 2010. Early Miocene hippopotamids (Cetartiodactyla) constrain the phylogenetic and spatiotemporal settings of hippopotamid origin. Proceedings of the National Academy of Sciences of the United States of America 107: 11871-11876.

Patrulius D. 1954. Asupra prezentei anthracoteridului Prominatherium dalmatinum $\mathrm{H}$. Meyer, in depozitele paleogene de la Sãcel (Maramures). Buletin Stiintific Sectiunea de Stiinte Biologice, Agronomice, Geologice si Geografice 6: 857-869.

Pickford M. 1987. Révision des Suiformes (Artiodactyla, Mammalia) de Bugti (Pakistan). Annales de Paléontologie 73: $289-350$.

Pickford M. 2016. Anthracotheres from the Oligocene of Aubenas-les-Alpes, France. Annales de Paléontologie 102: 243-260.

Rincon AF, Bloch JI, Macfadden BJ, Jaramillo CA. 2013. First central American record of Anthracotheriidae (Mammalia, Bothriodontinae) from the early Miocene of Panama. Journal of Vertebrate Paleontology 33: 421-433.

Roman F, Boucher J. 1936. Les mammifères stampiens du Bassin de Roanne (Loire): I. Anthracotherium bumbachense. Travaux des Laboratoires de Géologie de la Faculté des Sciences de Lyon 29: 1-48.

Rütimeyer L. 1857. Über Anthracotherium magnum und hippoideum. Neue Denkschriften der schweizerischen Naturforschen- den Gesellschaft 15: 1-32.

Scherler L. 2011. Terrestrial paleoecosystems of large mammals (Tapiridae, Anthracotheriidae, Suoidea) from the Early Oligocene to the Early Miocene in the Swiss Molasse Basin: biostratigraphy, biogeochemistry, paleobiogeography, and paleoecology. Unpublished D. Phil. Thesis, Fribourg University.

Scherler L, Mennecart B, Hiard F, Becker D. 2013. Evolutionary history of hoofed mammals during the Oligocene-Miocene transition in Western Europe. Swiss Journal of Geosciences 106: 349-369.
Scott WB. 1940. The mammalian fauna of the White River Oligocene: Part IV. Artiodactyla. Transactions of the American Philosophical Society 28: 363-746.

Sieber R. 1935. Ergebnisse paläontologischer Untersuchung an westeuropäischen Anthracotherien. Sitzungsberichte der Kaiserliche Akademie von Wissenschaften, mathematischnaturwissenschaftliche Klasse, Wien 5: 215-218.

Sieber R. 1936. Remarques sur les Anthracotherium de l'Oligocene français. Bulletin de la Société d'histoire naturelle de Toulouse 70: 351-361.

Soe AN. 2008. A new study of the anthracotheres (Mammalia, Artiodactyla) from Pondaung Formation, Myanmar: systematics implications. Palaeovertebrata 36: 89-157.

Soe AN, Chavasseau O, Chaimanee Y, Sein C, Jaeger JJ, Valentin X, Ducrocq S. 2017. New remains of Siamotherium pondaungensis (Cetartiodactyla, Hippopotamoidea) from the Eocene of Pondaung, Myanmar: Paleoecologic and phylogenetic implications. Journal of Vertebrate Paleontology 37: e1270290.

Squinabol S. 1890. Rivista dei grossi Anthracotherium di Cadibona. Bolletino della Societa Geologica Italiana 9: 515-571.

Stehlin HG. 1909. Remarques sur les faunules de mammifères des couches éocènes et oligocènes du Bassin de Paris. Bulletin Société Géologique de France 41: 488-520.

Stehlin HG. 1910. Zur Revision der europäischen Anthracotherien. Verhandlungen der naturforschenden Gesellschaft, Basel 21: 165-185.

Sudre J. 1978. Les artiodactyles de l'Eocène moyen et supérieur d'Europe occidentale: systématique et évolution. Mémoire et travaux de l'école pratique des hautes études, Institut de Montpellier 7: 1-229.

Sudre J. 1995. Le Garouillas et les sites contemporains (Oligocène, MP25) des Phosphorites du Quercy (Lot, Tarnet-Garonne, France) et leurs faunes de vertébrés: 12 . Artiodactyles. Palaeontographica 236: 205-256.

Swofford DL. 2002. PAUP* version 4.0. Phylogenetic analysis using parsimony (and other methods). Sunderland: Sinauer Associates.

Teller F. 1886. Neue Anthracotherium reste aus der Südsteiermark und Dalmatien. Beiträge zur Paläontologie Oesterreich-Ungarns 4: 45-133.

Tissier J, Becker D, Codrea V, Costeur L, Fărcaş C, Solomon A, Venczel M, Maridet O. 2018. New data on Amynodontidae (Mammalia, Perissodactyla) from the Eocene of Eastern Europe: phylogenetic and palaeobiogeographic implications. PLoS One 13: e0193774.

Tsubamoto T, Takai M, Egi N, Shigehara N, Tun ST, Aung AK, Soe AN, Thein T. 2002. The Anthracotheriidae (Mammalia; Artiodactyla) from the Eocene Pondaung Formation (Myanmar) and comments on some other anthracotheres from the Eocene of Asia. Paleontological Research 6: $363-384$.

Tsubamoto T, Zing-Maung MT, Egi N, Nishimura T, Taung-Htike, Takai M. 2011. A new anthracotheriid artiodactyl from the Eocene Pondaung formation of Myanmar. Vertebrata PalAsiatica 49: 85-113.

Tütken T, Absolon J. 2015. Late Oligocene ambient temperatures reconstructed by stable isotope analysis of 
terrestrial and aquatic vertebrate fossils of Enspel, Germany. Palaeobiodiversity and Palaeoenvironments 95: 17-31.

Vandenberghe N, Hilgen FJ, Speijer RP with contributions of Ogg JG, Gradstein FM, Hammer O, Hollis CJ, Hooker JJ. 2012. The Paleogene period. In: Gradstein FM, Ogg JG, Schmitz M, Ogg G, eds. The geologic time scale. Amsterdam: Elsevier, 855-921.
Viret J. 1961. Artiodactyla. In: Piveteau J, ed. Traité de paléontologie VI. Paris: Masson, 887-1104.

Zaw K, Meffre S, Takai M, Suzuki H, Burrett C, Htike T, Thein ZMM, Tsubamoto T, Egi N, Maung M. 2014. The oldest anthropoid primates in SE Asia: evidence from LA-ICP-MS $\mathrm{U}-\mathrm{Pb}$ zircon age in the Late Middle Eocene Pondaung Formation, Myanmar. Gondwana Research 26: 122-131.

\section{SUPPORTING INFORMATION}

Additional Supporting Information may be found in the online version of this article at the publisher's web-site:

Appendix S1. List and description of the 106 characters used in the cladistic analysis.

Appendix S2. List and description of material of the 25 taxa used in the cladistic analysis.

Appendix S3. Character-taxon matrix used for the cladistics analysis.

Appendix S4. Output file of cladistic analysis run with Paup4.0a151, including heuristic search results and list of apomorphies.

Appendix S5. Localities recording remains of Paenanthracotherium gen. nov. and Anthracotherium in the Oligocene of Europe and Asia.

Appendix S6. Dental measurements (in millimetres) of the three species of Paenanthracotherium gen. nov. and dental measurements (in millimetres) of species of Anthracotherium. 